\title{
Las aldeas del Formativo Inferior de la quebrada del Toro (Salta, Argentina)
}

RODOLFO RAFFINO ${ }^{1}$

\section{Introducción}

La quebrada del Toro es un estrecho bolsón de recorrido longitudinal que se comporta como eje central de un sistema de quebradas menores y laterales, ubicadas en el occidente de la provincia de Salta, en el ámbito de la cordillera Oriental y la prepuna. A lo largo de su trayecto, la quebrada mayor recibe el aporte de un conjunto de quebradas laterales como las de Morohuasi, Las Cuevas, Las Capillas, entre varias más. Geomórficamente, la región se compone de quebradas altas, estrechas y sinuosas, de agresivo perfil, con cabeceras en el altiplano puneño, a $4000 \mathrm{~m} . \mathrm{snm}$. Es precisamente este último accidente el que marca los límites norte y oeste de la región, mientras que por el este la sierra del Chañi la separa de la Quebrada de Humahuaca y el valle Grande de Jujuy. Hacia el sur este sistema de quebradas se conecta con los valles calchaquíes de la provincia de Salta.

Entre los rasgos físicos, climáticos y biológicos relevantes de la comarca, podemos considerar los de tipo geomórfico: fondos fértiles de quebradas con suelos arenoso-limosos de $\mathrm{pH}$ básico y gran drenaje; pie de montes de pendiente abrupta, poblados de abanicos aluviales y conos de deyección cuaternarios; ríos estacionales, muy agresivos en verano y casi desprovistos el resto del año. Clima continental, de cálido moderado a frío; con precipitaciones pluviales inferiores a $100 \mathrm{~mm}$ anuales, pero con elevado índice de heladas y neviscas (especialmente en zonas altas). Bruscas oscilaciones de temperaturas diurnas-nocturnas; bajo índice de humedad y alta radiación solar. Vegetación de tipo estepa arbustiva xerófila, condicionada por la rigurosidad climática, con algunas ingresiones de bosque xerófilo caducifolio en el sur. Presencia de una fauna autóctona en proceso de extinción, compuesta por llamas, guanacos y vicuñas (Fam. Camelidae), puma

CONICET, Facultad de Ciencias Naturales y Museo, Universidad Nacional de La Plata, La Plata, ARGENTINA.
(Fam. Felidae), zorro (Fam. Canidae), patos (Ord. Anseriformes), flamencos (Ord. Ciconiformes), "suri" (Ord. Rehiforme) y roedores varios (Fam. Ctenomidae, Chinchilidae, etc.).

Un relevante segmento de registro arqueológico, colectado en seis sitios del Período Formativo Inferior: Cerro El Dique, Potrero Grande, la Encrucijada, Las Capillas, La Mina y Las Cuevas, permite presentar, aquí, el estado actual de la información, además de aspectos interpretativos, inherentes a la arqueología, y específicos para este momento del proceso cultural aborigen. De estos sitios, serán tratados con especial énfasis los dos primeros, utilizándose los restantes a modo comparativo, mediante el mecanismo de analogías y disimilitudes, teniendo como meta la integración del contexto, o modelo arqueológico, de las formas de vida de las aldeas formativas inferiores, en el tiempo y espacio delimitado.

Un breve repaso a la historia de las investigaciones arqueológicas de la región nos introduce en las tempranas contribuciones efectuadas por Boman (1908) y von Rosen (1916), ambas excelentes para su época; luego un prolongado silencio científico que se extiende por espacio de 60 años y que motivó un notorio atraso en la colecta de información e interpretación cultural. Este período vacío de investigaciones fue afortunadamente superado con los trabajos que, a partir de 1967, emprendiera la División Antropología del Museo de La Plata, fruto de los cuales se han dado ya a conocer poco más de una docena de trabajos, considerando aspectos de la problemática arqueológica. Entre ellos los de Cigliano (1968, 1970 y 1973), Cigliano y Calandra (1971), Cigliano y Raffino (1973, 1974 y 1975), Cigliano y colaboradores (1972) y Raffino (1968, $1970,1972,1973$ y 1975). ${ }^{2}$

2 El sitio Las Cuevas ha merecido una contribución a cargo de Cigliano (1970) y de Cigliano y colaboradores (1972). Recientes investigaciones efectuadas han permitido ampliar considerablemente los conocimientos de Las Cuevas, 


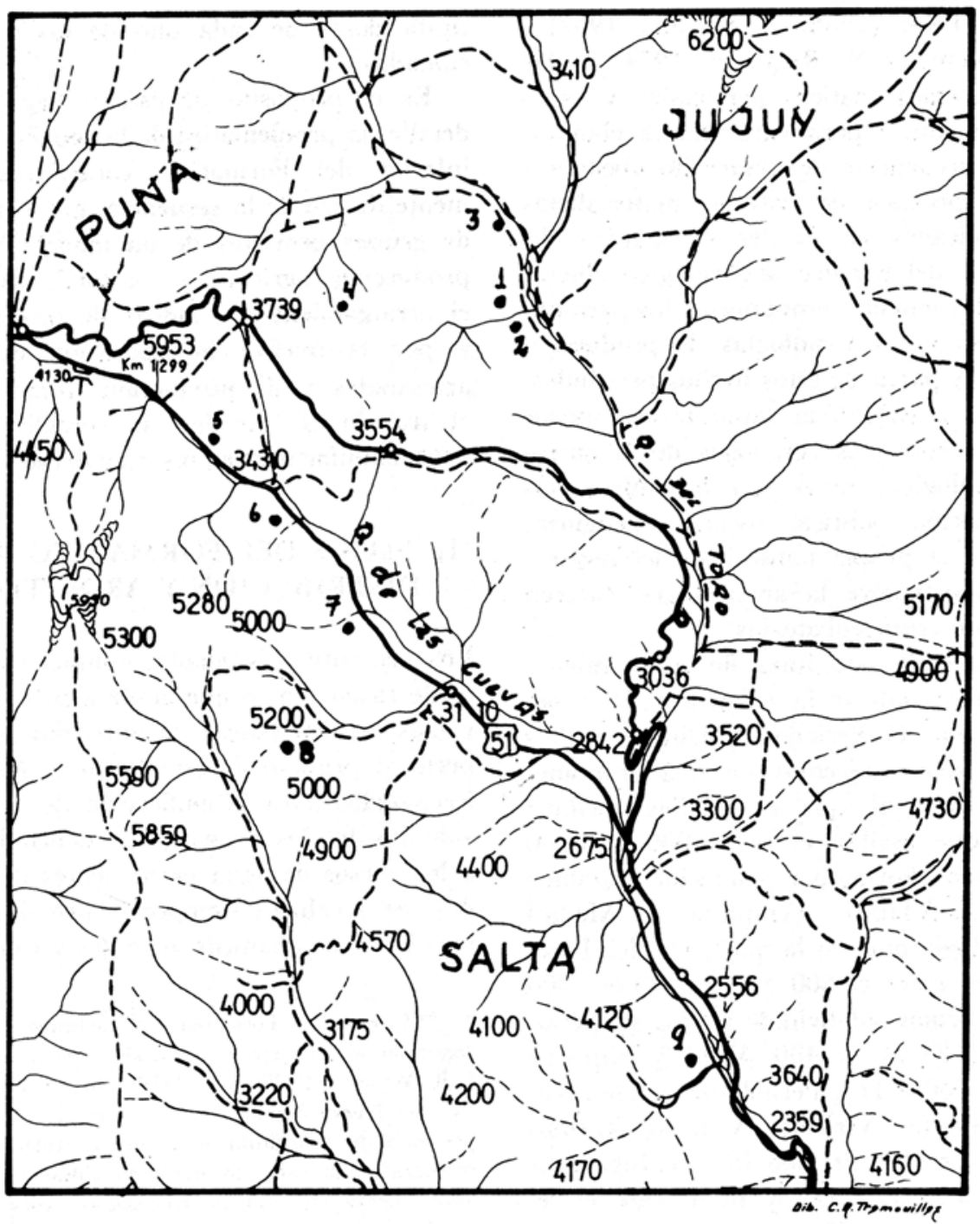

Figura 1. Mapa de la región de la quebrada del Toro. Ubicación de los sitios del Formativo: Formativo Inferior: 1) Cerro El Dique; 2) Potrero Grande; 5) La Encrucijada; 6) Las Cuevas; 7) La Mina; 8) Las Capillas. Formativo Superior: 3) Tres Cruces; 4) Cerro La Aguada; 9) El Gólgota.

Para conceptualizar el dinamismo y evolución cultural de esta región es necesario formular, previamente, un modelo de proceso que tipifique el pasaje del nomadismo al sedentarismo, de la colecta simple de alimentos a la producción de ellos, del perfeccionamiento tecnológico, del aumento demográfico, del pasaje de los poblados aldeanos dispersos a los centros urbanizados, etc. Para la quebrada del Toro y comarcas vecinas es factible construir este modelo de proceso cultural siguiendo un poco anteriores líneas

además de nuevos registros de $\mathrm{C}^{14}$, los que serán prontamente publicados.. trazadas por investigadores como Uhle (1912), Bennett (1948), González (1955 y 1963), González y Pérez (1966), Serrano (1967) y más recientemente Núñez Regueiro (1974), a las que incorporaremos matices personales y específicos a la región. Operativamente, la elaboración de estas secuencias de desarrollo obedece a la puesta en práctica de criterios materialistas culturales, aplicados en niveles de análisis directos, a partir del registro arqueológico obtenido. Ellos son los modelos económicos, los patrones de poblamiento y las tecnologías de producción y artesanales. A partir de estos hechos percibidos, son alcanzados a considerar, aunque con menor intensidad, aspectos más complejos de la antropología arqueológica, 
como son las inferencias sobre organización política, social y religiosa, los cuales, por la propia naturaleza del registro con que se desenvuelve la arqueología, carecen de demostraciones comprobatorias.

Sobre la base de esta línea de razonamiento es factible conceptualizar la existencia de cinco períodos. Ellos son: el Período Paleoindio o Precerámico, del que carecemos de una cronometría precisa, pero al que es posible atribuir antigüedades que oscilan entre 15000 a 8000 AC; el Período Formativo (conocido también como Agrícola Alfarero Temprano y Medio) con una cronología que, en la quebrada del Toro, puede jalonarse entre $600 \mathrm{AC}$ a 900 o $1000 \mathrm{DC}$ y al que hemos subdividido en dos subperíodos: Inferior (600 AC a 400 DC) y Superior (400 a 900 o 1000 DC); Período de los Desarrollos Regionales (o Agrícola Alfarero Tardío) (1000 a 1470 DC); Período Inca (o Inca Provincial) (1470 a 1535 DC), y, finalmente, el Período Colonial, cuyo inicio puede signarse a partir de la entrada de Diego de Rojas y sus compañeros, en el Noroeste Argentino, en 1543 en adelante. A estos cinco períodos mencionados es posible adicionar el Período Arcaico, Protoformativo o Agrícola Incipiente, cuyas manifestaciones culturales están siendo exhumadas con relevante intensidad a pocos kilómetros de la cabecera septentrional de la quebrada del Toro, entre las estribaciones occidentales de la vecina Quebrada de Humahuaca, por Fernández Distel y colaboradores (1973, 1974 y 1975). La obtención de cuatro fechados radiocarbónicos asociados a un contexto arcaico, en las cuevas de Huachichocana e Inca Cueva, permite ubicar a este período entre 7000 a 600 AC. En el Cuadro 1 se expone, dentro de la secuencia establecida, la lista de sitios arqueológicos, los fechados radiocarbónicos, así como los rasgos culturales tipificadores de cada uno de los períodos mencionados.

Es el propósito de este trabajo analizar, en detalle, la problemática de la sección o subperíodo inferior del Formativo, caracterizado culturalmente dentro de la secuencia por el advenimiento de grupos provistos de un modelo económico de producción agrícola y pastoril, así como por el arraigamiento de aldeas de ocupación estable y por la masiva incorporación de tecnologías artesanales y de producción, como la alfarería, el trabajo en metales, la cordelería y cestería y las manufacturas en piedra y hueso. ${ }^{3}$

3 E1 término "Formativo" es aplicado en este trabajo siguiendo los conceptos expresados en su oportunidad por Willey y Phillips (1958: 146), es decir, el "Formativo del Nuevo Mundo"

\section{Sitios del Formativo Inferior, distribución y arquitectura}

Los seis sitios estudiados comparten un conjunto de rasgos en lo que atañe a su emplazamiento y sus características arquitectónicas. Con respecto al primero de estos tópicos, los lugares seleccionados para la edificación de las aldeas han sido los fondos y márgenes deprimidos, vecinos a los cursos de agua permanentes de las quebradas. Se localizan siempre dentro de los sectores más bajos de abanicos aluviales y conos de deyección cuaternarios, nunca por encima de los 15 a $20 \mathrm{~m}$ por sobre el nivel del río. Entre esa posición elegida para el emplazamiento de las aldeas y el curso de agua, dentro de la llamada franja fértil, se han dispuesto los campos agrícolas vinculados a las aldeas.

Cerro El Dique y Potrero Grande están situados a ambos lados del río Punta Ciénaga, en la cabecera septentrional de la quebrada del Toro, a 3100 m.snm; separados entre sí por $1 \mathrm{~km}$, extensión ocupada en la actualidad por la llanura aluvial del río. Las Cuevas y La Encrucijada ocupan, respectivamente, los márgenes derecho e izquierdo del río Las Cuevas, en la quebrada homónima, a 3400 m.snm. Están distantes entre sí por $4 \mathrm{~km}$. La aldea de La Mina se edificó sobre la terraza inferior del margen derecho del río Las Cuevas, a $8 \mathrm{~km}$ al sur de Las Cuevas.

es un estadio caracterizado por la presencia de agricultura, o de otra actividad de subsistencia comparable, la vida sedentaria en aldeas estables y por el advenimiento de nuevas tecnologías, como la alfarería, textilería, la escultura lítica, la arquitectura ceremonial, entre otros bienes. Para el ámbito que nos ocupa, este estadio de cultura llamado "Formativo" se presenta notoriamente pauperizado y cronológicamente desfasado -por razones de marginalización-, en relación al Formativo del centro nuclear andino o Area Andina Central. Ello ha dado lugar a la tendencia de algunos autores, como Bennett y colaboradores (1948) y González (1955 y 1963a.) de proponer otros esquemas periodificadores más específicos, en los cuales el Formativo, en su subperíodo Inferior, equivale al llamado Período Agrícola Alfarero Temprano, o, también, siguiendo a Menguin, Período Neolítico Regional; además se ha utilizado la denominación de Formativo Regional Subandino, la cual también es operativa. Este caso específico de periodificación es extensible a todo el ámbito de la llamada Area Andina Meridional, incluyendo el Noroeste Argentino, norte de Chile y sección meridional de Bolivia. En este trabajo, viendo el espectro cultural en términos de "proceso", de acuerdo con criterios periodificadores en etapas de desarrollo "homotaxiales", utilizables para toda el Area Andina, considero mucho más válido y operativo aplicar el término Formativo. 
RODOLFO RAFFINO

\begin{tabular}{|c|c|c|c|c|c|c|c|}
\hline 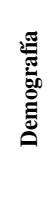 & \multicolumn{2}{|c|}{ 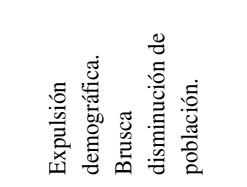 } & 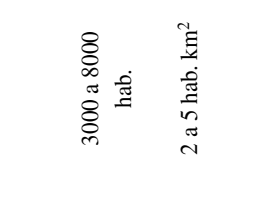 & 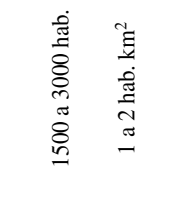 & 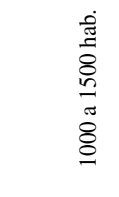 & 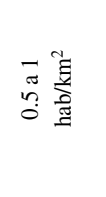 & \\
\hline 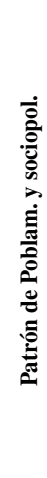 & 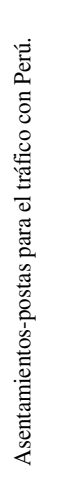 & 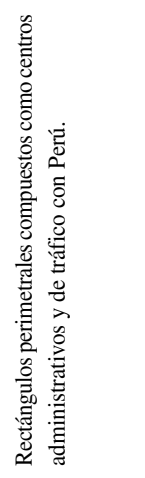 & 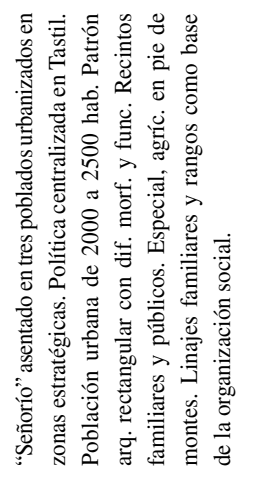 & 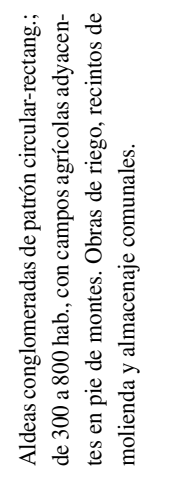 & 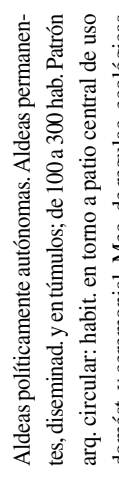 & 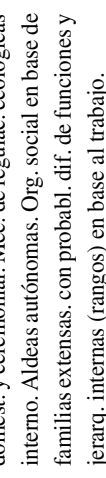 & \\
\hline 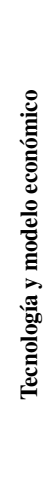 & 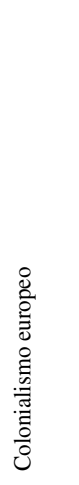 & 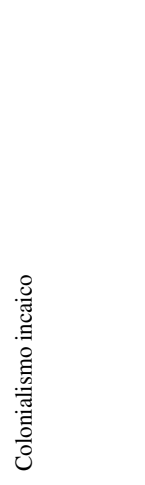 & 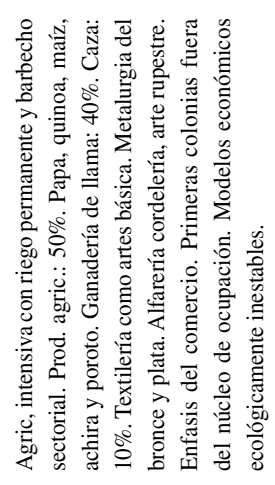 & 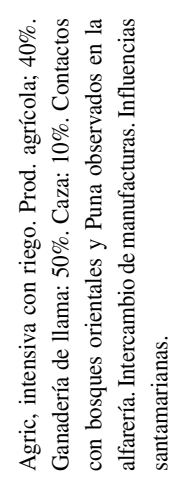 & 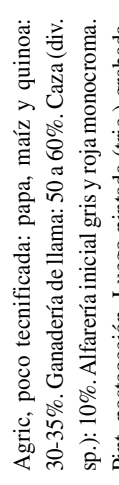 & 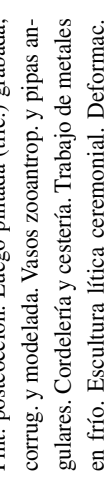 & \\
\hline 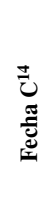 & 1 & 1 & 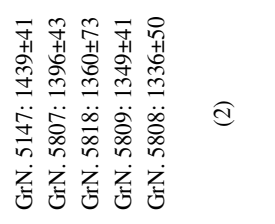 & 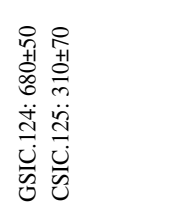 & 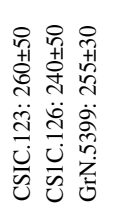 & 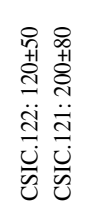 & 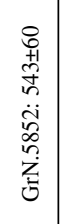 \\
\hline 啄 & 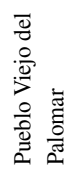 & 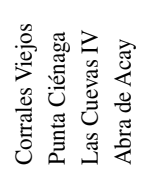 & 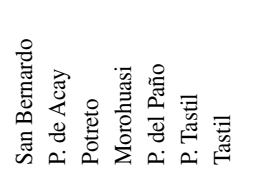 & 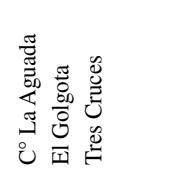 & 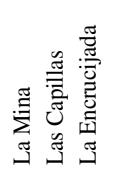 & 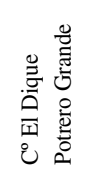 & 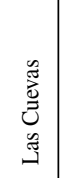 \\
\hline 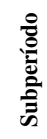 & & & & 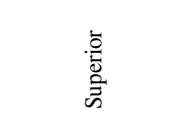 & & 总 & \\
\hline 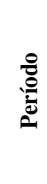 & 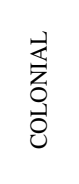 & 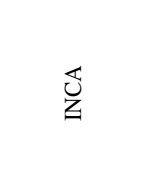 & 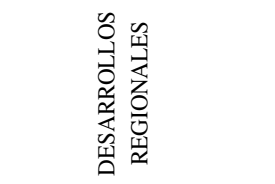 & 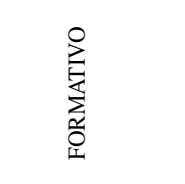 & & & \\
\hline 䙔 & 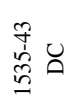 & 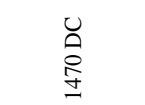 & $\begin{array}{l}0 \\
\stackrel{0}{\circ} \\
\stackrel{0}{0}\end{array}$ & $\begin{array}{l}\text { O } \\
\text { \&্ج }\end{array}$ & & & \\
\hline
\end{tabular}




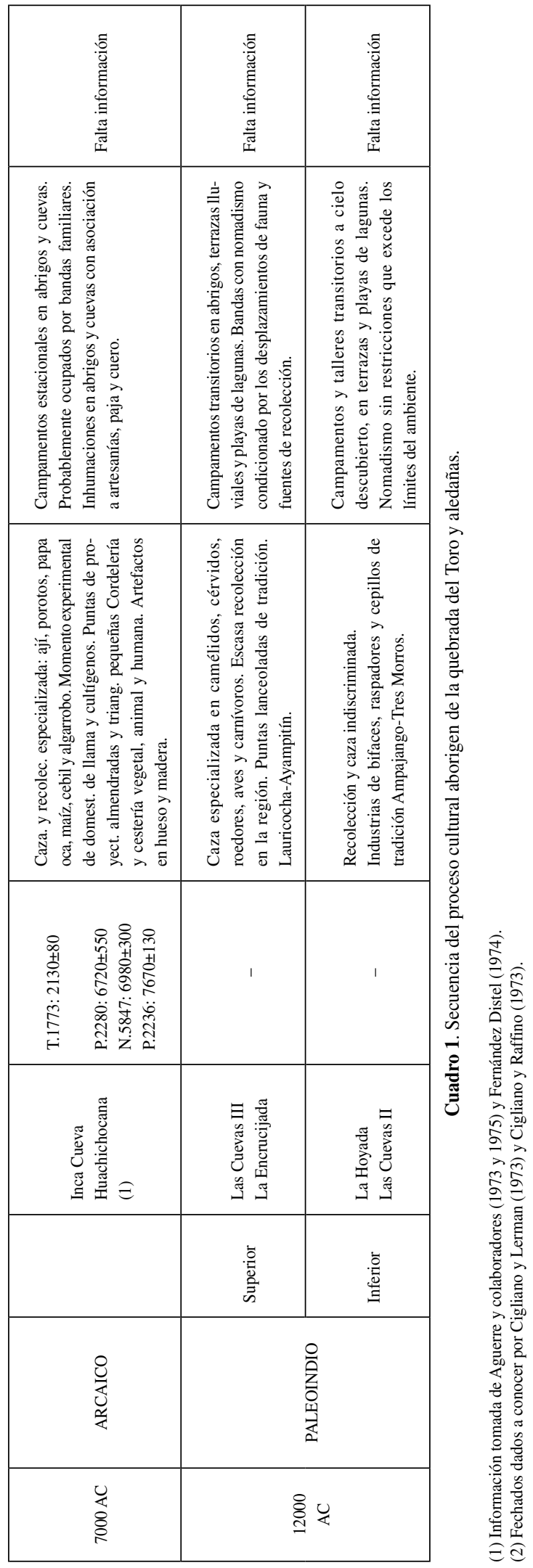


Las Capillas se encuentra en la quebrada del mismo nombre, sobre una terraza del margen izquierdo del río, a $3000 \mathrm{~m} . \mathrm{snm}$.

Cuatro de las aldeas: Cerro El Dique, Potrero Grande, La Encrucijada y Las Capillas, responden a poblamientos dispersos, sobre terrenos de poca pendiente (menor de 5\%), presentando espacios libres entre las construcciones. El sitio Las Cuevas ofrece un poblamiento más concentrado que los anteriores (coincidiendo con un más prolongado tiempo de ocupación), en una pendiente de 10\%. En este sitio se observan superposiciones de elementos arquitectónicos en un mismo lugar, conformando montículos o túmulos de doble origen: natural y artificial. Las construcciones se efectuaron, en un primer momento, sobre elevaciones naturales del abanico aluvial; posteriormente, cuando por causas accidentales o motivadas la construcción se destruía, sobre ese mismo lugar era edificada otra, produciéndose una elevación del túmulo. En los montículos norte y oeste de Las Cuevas se comprobaron superposiciones de hasta cinco unidades arquitectónicas de igual o diferente función (viviendas, patios, tumbas y basurales), ubicadas una encima de la otra.
El sitio restante, La Mina, solamente proporcionó, hasta el presente, evidencias arqueológicas correspondientes a inhumaciones de adultos en tumbas.

Con respecto a los rasgos arquitectónicos de los sitios, ellos responden a una serie de cánones compartidos, que fueron tenidos en cuenta para la construcción. Estos rasgos compartidos han sido agrupados a manera de síntesis en el Cuadro 2, y que son válidos para definir el término "aldea", tal como es aplicado aquí.

Tipo de emplazamiento:

1. En fondos y márgenes deprimidos de quebradas.

2. Sobre uno o dos lados de un curso de agua permanente.

3. Poblamiento disperso sobre terrenos planos.

4. Poblamiento concentrado en montículos con superposiciones de arquitectura.

\begin{tabular}{|c|c|c|c|c|c|c|}
\hline Rasgo & $\begin{array}{c}\text { Cerro } \\
\text { El Dique }\end{array}$ & Las Cuevas & Potrero Grande & La Encruc. & Las Capillas & La Mina \\
\hline 1 & $\mathrm{X}$ & $\mathrm{X}$ & $\mathrm{X}$ & $\mathrm{X}$ & $\mathrm{X}$ & $\mathrm{X}$ \\
\hline 2 & $\mathrm{X}$ & $\mathrm{X}$ & $\mathrm{X}$ & $\mathrm{X}$ & $\mathrm{X}$ & $\mathrm{X}$ \\
\hline 3 & $\mathrm{X}$ & - & $\mathrm{X}$ & $\mathrm{X}$ & $X$ & $\mathrm{X}$ \\
\hline 4 & - & $\mathrm{X}$ & - & - & - & - \\
\hline 5 & $\mathrm{X}$ & $X$ & $X$ & $X$ & $\mathrm{X}$ & $X$ \\
\hline 6 & $\mathrm{X}$ & $X$ & - & $\mathrm{O}$ & $\mathrm{O}$ & $\mathrm{O}$ \\
\hline 7 & $\mathrm{X}$ & $\mathrm{X}$ & $\mathrm{X}$ & $\mathrm{X}$ & $\mathrm{X}$ & $\mathrm{O}$ \\
\hline 8 & $\mathrm{X}$ & $\mathrm{X}$ & $\mathrm{X}$ & $\mathrm{X}$ & $\mathrm{X}$ & $\mathrm{O}$ \\
\hline 9 & $\mathrm{X}$ & $\mathrm{X}$ & - & $\mathrm{X}$ & $X$ & $\mathrm{O}$ \\
\hline 10 & - & $\mathrm{X}$ & $X$ & $\mathrm{X}$ & $\mathrm{X}$ & $\mathrm{O}$ \\
\hline 11 & $\mathrm{X}$ & $\mathrm{X}$ & $\mathrm{X}$ & $\mathrm{X}$ & $\mathrm{X}$ & $\mathrm{O}$ \\
\hline 12 & $\mathrm{X}$ & $\mathrm{X}$ & $\mathrm{X}$ & $\mathrm{X}$ & $\mathrm{X}$ & $\mathrm{O}$ \\
\hline 13 & - & - & - & - & - & $\mathrm{O}$ \\
\hline 14 & $\mathrm{X}$ & $\mathrm{X}$ & $X$ & $X$ & $\mathrm{X}$ & $\mathrm{O}$ \\
\hline 15 & $\mathrm{X}$ & $\mathrm{X}$ & $\mathrm{X}$ & $\mathrm{X}$ & $\mathrm{X}$ & $X$ \\
\hline 16 & $\mathrm{X}$ & $\mathrm{X}$ & $\mathrm{X}$ & $\mathrm{X}$ & $\mathrm{X}$ & $\mathrm{X}$ \\
\hline 17 & $\mathrm{X}$ & $\mathrm{X}$ & - & - & $X$ & $\mathrm{O}$ \\
\hline 18 & - & $\mathrm{X}$ & $X$ & $\mathrm{O}$ & $\mathrm{O}$ & $X$ \\
\hline 19 & $\mathrm{X}$ & $\mathrm{X}$ & $X$ & - & $\mathrm{O}$ & $\mathrm{O}$ \\
\hline 20 & $X$ & $X$ & - & $\mathrm{O}$ & $\mathrm{O}$ & $\mathrm{O}$ \\
\hline
\end{tabular}

Cuadro 2. Lista de rasgos (X: presencia; - ausencia; O: falta registro). 
19. Asociación con campos agrícolas e indirectamente con estepas para pastoreo y cotos de caza (medio aldeano-rural).

Rasgos arquitectónicos:

5. Arquitectura en piedra y adobe con techo perecible.

6. Habitaciones pequeñas concentradas en torno a patios centrales.

7. Habitaciones pequeñas aisladas.

8. Planta circular en habitaciones y patios.

9. Paredes de piedras rectangulares ensambladas con barro batido y ripio.

10. Paredes de piedras subglobulares ensambladas con barro batido y ripio.

11. Construcciones semisubterráneas, con cimientos e inicio de paredes de piedra. Terminadas con techo de material perecible.

12. Paredes dobles con relleno de barro batido y ripio.

13. Entradas o aberturas en las construcciones.

14. Techos de material perecible (ramas, madera, pieles, barro).
15. Ausencia de techos y construcciones ceremoniales en los patios.

16. Tumbas de adultos en forma cilíndrica, con techo de lajas seleccionadas y paredes de suelo natural.

17. Tumbas ubicadas debajo de los patios centrales (piso cultural).

18. Tumbas ubicadas fuera del perímetro de la aldea.

20. Hornos o fogones de piedra, ubicados en los patios centrales.

Las excavaciones emprendidas sobre diferentes unidades, morfológicas y funcionales de los sitios, abarcan un total de cuatro patios centrales, 10 habitaciones, ocho basurales, 16 tumbas, una muralla defensiva (de contención de derrumbes) y dos hornos-fogones. Su discriminación es la siguiente (Cuadro 3):

En Cerro El Dique los patios excavados responden a las siglas C.D.U.H.1/3/4. Las habitaciones, cinco en total, a C.D.U.H.1.a/2/5/6/7. Los basurales a C.D.s.17/18. Las tumbas, ocho en total, a C.D.t.1/2/3/4/6/7/10/11. Con excepción de las tumbas C.D.t.10 y C.D.t.11, las restantes están ubicadas por debajo del piso del patio C.D.U.H.4. La tumba C.D.t.10 estaba aloja-

\begin{tabular}{|c|c|c|c|c|c|c|}
\hline Sitio Unidad & Patio & Habitación & Basural & Tumba & Muralla & Horno-fogón \\
\hline Cerro El Dique & $\begin{array}{l}\text { C.D.U.H.1 } \\
\text { C.D.U.H.3 } \\
\text { C.D.U.H.4 }\end{array}$ & $\begin{array}{l}\text { C.D.U.H.2.a } \\
\text { C.D.U.H.2 } \\
\text { C.D.U.H.5 } \\
\text { C.D.T.H.6 } \\
\text { C.D.U.H.7 }\end{array}$ & $\begin{array}{l}\text { C.D.s. } 17 \\
\text { C.D.s. } 18\end{array}$ & $\begin{array}{c}\mathrm{t} .1 \\
\mathrm{t} .2 \\
\mathrm{t} .3 \\
\mathrm{t} .4 \\
\mathrm{t} .6 \\
\mathrm{t} .7 \\
\mathrm{t} .10 \\
\mathrm{t} .11\end{array}$ & - & C.d.s.8 \\
\hline Potrero Grande & - & P.G.UH.1 & $\begin{array}{l}\text { P.G.s.1 } \\
\text { P.G.s. } 2 \\
\text { P.G.s.3 } \\
\text { P.G.s.4 }\end{array}$ & t.1 & - & - \\
\hline La Encrucijada & - & L.E.U.H.1 & - & t. 1 & - & - \\
\hline Las Capillas & - & - & - & t.1 & - & - \\
\hline La Mina & - & - & - & t.1 & - & - \\
\hline Las Cuevas(*) & $\begin{array}{c}\text { L.C.U.H } \\
\text { s/n }\end{array}$ & $\begin{array}{l}\text { L.C.U.H.4 } \\
\text { L.C.U.H.5 } \\
\text { L.C.U.H.6 } \\
\text { L.C.U.H.7 } \\
\text { L.C.U.H.8 } \\
\text { L.C.U.H.9 }\end{array}$ & $\begin{array}{l}\text { L.C.M.N } \\
\text { L.C.M.O }\end{array}$ & $\begin{array}{l}\text { t. } 1 \\
\text { t. } 2 \\
\text { t. } 3 \\
\text { t. } 4\end{array}$ & 1 & L.C.s.17 \\
\hline
\end{tabular}

Cuadro 3. Detalle de las excavaciones (*efectuadas por Cigliano y colaboradores. El resto, efectuadas por el autor). 
da debajo del patio central C.D.U.H.1. La tumba C.D.t.11, debajo del patio C.D.U.H.3.

En Potrero Grande las excavaciones se efectuaron dentro de una habitación, que responde a la sigla P.G.U.H.1; cuatro basurales: P.G.s.1/2/3/4 y una tumba hallada aisladamente: P.G.t.1.

En La Encrucijada se excavó una habitación que responde a la sigla L.E.U.H.1 y en una tumba hallada aisladamente: L.E.t.1. En Las Capillas se excavó una tumba: L.Ca.t.1. En La Mina una tumba que fue hallada por un agricultor: L.M.t.1.

En Las Cuevas las excavaciones fueron efectuadas durante tres campañas por los autores mencionados en la nota 2. Sobre un total de seis habitaciones, un patio central, dos basurales ubicados en los montículos norte y oeste, un horno-fogón, una muralla de contención de derrumbes y cuatro tumbas: L.C.t. $1 / 2 / 3 / 4$.

Para efectuar un análisis detallado de la arquitectura de las aldeas tomaremos como base a Cerro El Dique, la más relevante de todas, tanto por sus dimensiones como por su óptimo estado de conservación. Se trata de un poblamiento ubicado en una escasa pendiente (5\%), en la margen izquierda del río. Ocupa una superficie de $16.000 \mathrm{~m}^{2}$, sin incluir los terrenos destinados a la agricultura. En Cerro El Dique se ha podido detectar la presencia de 43 recintos de planta circular y paredes de piedra; de éstos, siete pueden corresponder a patios centrales y 37 a habitaciones. Las construcciones de Cerro El Dique pueden ser clasificadas, apelando a criterios morfológicos y funcionales, en siete tipos (estas categorías son válidas también para los restantes sitios), a saber: habitaciones, patios, tumbas, basurales, campos agrícolas y hornos-fogones.

a) Habitaciones. De planta circular y elíptica. Poseen de 2 a $5 \mathrm{~m}$ de diámetro. Fueron construidas con piedras lajas clavadas verticalmente en el piso, que sirven como cimientos y paredes. El relleno de las paredes se efectuó con barro batido y ripio. El cierre de estas construcciones ha sido hecho con materiales perecibles (madera, ramas, barro, etc.). Las paredes de piedra y adobe no exceden nunca los $0.80 \mathrm{~m}$ de altura; pueden ser simples y dobles; en este último caso, están rellenas con barro y ripio entre paredes (externa e interna), poseyendo hasta $0.60 \mathrm{~m}$ de espesor.
Las habitaciones se disponen de dos formas: o bien en forma radial, concéntricas a un patio central, en número de 1 a 5 ; o en forma aislada. Por debajo del piso cultural, que no excede nunca los 0.80 a $1 \mathrm{~m}$ de profundidad, puede hallarse un espacio destinado para el fogón. Todas las habitaciones son semisubterráneas. ${ }^{4}$

b) Patios. Poseen características arquitectónicas similares a las habitaciones; semisubterraneidad, planta circular y elíptica, paredes de piedras lajas clavadas verticalmente en el piso, etc. Se diferencian de aquéllas por sus grandes dimensiones, de 8 a $15 \mathrm{~m}$ de diámetro y por presentar siempre paredes dobles de piedra, rellenas con barro y ripio. Estos patios han carecido de techumbre.

Es muy importante destacar que dentro del sedimento de estos patios se ha obtenido un prolífico registro arqueológico, compuesto por utensilios varios destinados al uso doméstico y artesanal: grandes ollas utilizadas como depósitos, hornos o fogones construidos con paredes de piedra, gran variedad de instrumentos de molienda (morteros, molinos planos y manos), alfarería fragmentada y restos orgánicos de diversa índole. Todos ellos destacan la función primordial de estos patios como lugares destinados a las prácticas de los servicios domésticos y artesanales. Aunque tampoco debe descartarse la posibilidad de que algunos de estos recintos hayan sido utilizados como corral para encerrar llamas.

La funcionalidad de estos patios centrales no se agota todavía; por debajo del piso de los mismos fueron descubiertas las tumbas para inhumaciones de adultos e infantes. Destinados, tal vez, a los individuos que habitaron los recintos de vivienda contiguos al patio. Uno de estos grandes patios de Cerro El Dique, el C.D.U.H.4, ubicado al noreste de la aldea, presenta, además de los rasgos apuntados, dimensiones extraordinarias; $19.50 \mathrm{~m}$ de diámetro norte-sur y $15.10 \mathrm{~m}$ de diámetro este-oeste; es decir, una superficie de $294.4 \mathrm{~m}^{2}$. En su interior habían siete

4 Una analogía, de corte etnográfico, con estas habitaciones del Formativo son las llamadas "casas pozo y semipozo" de cimientos de piedra y materiales perecibles formando paredes y techo (se usa también el guano) descritas por Vivante y Palma (1966) en la región puneña. Tanto en esa zona como en la quebrada del Toro este tipo de construcción persiste en las estepas altas, siendo utilizada como vivienda transitoria de pastores. 
tumbas para adultos. Algunas de las cuales estaban por debajo de los $2 \mathrm{~m}$ de profundidad.

c) Tumbas. Se trata de pozos cilíndricos de paredes de tierra. Fueron excavadas en el piso de los patios centrales, de modo tal que puede hallárselas entre 1.30 a $2.50 \mathrm{~m}$ de profundidad con relación al piso cultural. Poseen techo de lajas muy bien construido, cuyo diámetro supera siempre al del pozo. Por sus dimensiones estas tumbas sólo han permitido la inhumación de un individuo adulto en posición genuflexa, o bien enterratorios de carácter secundario. Los hallados hasta el momento corresponden al primer caso.

Las dimensiones promedio de las tumbas son las siguientes: diámetro del pozo de 0.30 a $0.80 \mathrm{~m}$; altura de 0.30 a $0.80 \mathrm{~m}$; tapa de lajas de $0.30 \mathrm{~m}$ de espesor y diámetro mayor de $0.50 \mathrm{~m}$ que el del pozo.

d) Hornos-fogones. Son construcciones excepcionales hallados dentro de los patios centrales C.D.U.H.4, y en Las Cuevas L.C.s. 17 dentro del montículo oeste. Poseen planta circular y paredes de piedra y barro, con un diámetro de $0.80 \mathrm{~m}$ y $0.50 \mathrm{~m}$ de altura. El hallado en Cerro El Dique presentaba también restos de un techo de piedra. Ambas construcciones proporcionaron señales notorias de haberse usado para cocer materiales, incluso quizás alfarería.

e) Basurales. Se los encontró con frecuencia dentro de los patios centrales o bien contiguos a las habitaciones y patios. Aunque carecen de elementos arquitectónicos propios, han sido incluidos dentro de este capítulo porque poseen una estructura y funcionalidad bien definida, a la vez que ocupan espacios físicos dentro de unidades arquitectónicas mayores.

Provistos de una gran compactación, así como de notoria variedad de restos culturales y orgánicos, los basurales de Cerro El Dique, así como de los restantes sitios formativos inferiores de la quebrada del Toro, han proporcionado la mayor parte del registro arqueológico que es aquí tratado. La gran compactación mencionada, así como el hecho de poseer hasta $1.20 \mathrm{~m}$ de espesor, nos ofrece una prueba clara del largo lapso de ocupación de algunas de las aldeas, especialmente Cerro El Dique, Las Cuevas y Potrero Grande. Estos basurales han sido un documento arqueológico inmejorable también para la extracción de muestras para radiocarbono.
Entre los restos hallados en los basurales pueden mencionarse los orgánicos: restos de maíz carbonizado, calabazas, huesos de camélidos (llama, guanaco y vicuña); carnívoros (puma y zorro); aves (patos silvestres) y roedores varios. Entre todos ellos es notoria la gran concentración de restos orgánicos de camélidos.

Entre los vestigios de tecnologías hallados en los basurales pueden mencionarse unos 6000 fragmentos de cerámica de diversos tipos, cuerdas trenzadas en fibra vegetal y animal (pelo de llama), morteros cóncavos, molinos planos y manos de diversos tamaños; torteras, machacadores, sobadores, cascanueces, pulidores, hachas pulidas con cuello, cuchillos dentados, puntas de proyectil con pedúnculo y de base escotada, raspadores, bolas arrojadizas, sopladores o pipas de piedra, platos y fuentes de piedra y una placa grabada. Artefactos en hueso como espátula, punzones, tubos, silbatos, conchas de caracol terrestre pulidas, cuentas de collar. Artefactos en madera como astiles, palillos para hacer fuego y madera carbonizada, husos para textilería y fragmentos diversos. Algunos útiles en metal, como un anillo de cobre y restos de cobre y galena en estado natural.

Todos los materiales mencionados con notorias huellas de utilización y fragmentados.

f) Campos agrícolas. Esta es la evidencia arquitectónica más débil de todas las mencionadas. Solamente en Cerro El Dique y Potrero Grande se localizaron indicios de canchones destinados a la agricultura. Están ubicados inmediatamente al lado de la aldea, dentro de la franja fértil comprendida entre ésta y el margen del río. Ha sido imposible precisar con exactitud la extensión de estos terrenos. Los relictos de canchones poseen planta irregular, delimitados por paredes de piedra o, simplemente, por elevaciones de tierra. Se construyeron en suelos contiguos a la playa del río, detalle que permite inferir el empleo de las aguas para inundar, o bien regar manualmente los cultivos. Pero no se ha detectado ningún indicio arqueológico del empleo de regadío artificial. Los restantes sitios sufrieron la reutilización de los terrenos de la franja fértil, de modo tal que su comprobación hacia finalidades agrícolas ha sido imposible.

\section{Tecnologías muebles}

a) Alfarería. Conjuntamente con la arquitectura y el patrón de poblamiento, ocupa un lugar destacado 
dentro de este trabajo, por ser uno de los indicadores jerarquizados del contexto. La tipología de la cerámica que es presentada fue elaborada a partir del análisis de 50 piezas extraídas por nosotros, además de unos 4500 fragmentos provenientes de los basurales. También se tuvieron en cuenta las piezas de colección obtenidas en la región.

Tipo 1. Las Cuevas Gris Pulido

Otros nombres: Las Cuevas Negro Pulido (Cigliano 1970), Cerro El Dique Gris Pulido (Raffino y Togo 1970); Potrero Grande Gris Pulido (Raffino 1972).

Sitio tipo: Las Cuevas, depto. Rosario de Lerma, provincia Salta.

Pasta: Método de manufactura en rodete, escaso modelado.

Antiplástico: Escaso antiplástico arenoso (60\%). Proporción total estimada de 10 a $12 \%$. Compuesto por cuarzo tenido, con hematita, que predomina sobre la variedad límpida; el primero subredondeado, el segundo de forma angulosa y subangulosa. Vidrio volcánico en individuos limosos finos, fresco y muy anguloso a anguloso. Escasa plagioclasa de composición andesina, fresca y subangulosa, ortoclasa medianamente alterada de forma subredonda. Entre los pesados se destacan biotita y hornblenda, a los que se asocian muy escasos piroxeno (augita), apídoto y circón. ${ }^{5}$

Textura: Muy poco porosa, antiplástico bien distribuido, con finas burbujas de aire.

Color: Gris, con tonalidades marrones, núcleo más obscuro.

\section{Cocción: Reductora; dureza: 4.}

Superficies: Color gris, con zonas localizadas de tonalidades más obscuras.

Tratamiento: Superficie interna, pulidas en las piezas de silueta no restringidas. Superficie externa pulida.

5 Los análisis microscópicos de la alfarería fueron efectuados por el Dr. Luis Spalletti de la Facultad de Ciencias Naturales y Museo, Universidad Nacional de La Plata.
Formas:

A. Ollas

A.1 Ollas de silueta restringida, cuerpo globular, cuello estrangulado; borde evertido y suavemente directo; labio convexo. Base apenas insinuada. Con asas horizontales, simétricas, de sec. plana. Altura máxima, $350 \mathrm{~mm}$; altura mínima, 219 mm; diám. máximo, 400 mm; diám. mínimo, $176 \mathrm{~mm}$.

A.2 Ollas de silueta restringida, cuerpo globular, cuello estrangulado, borde fuertemente evertido y reforzado. Con base plana. Dimensiones similares a A.1.

A.3 Ollas de silueta restringida, cuerpo subglobular; cuello estrangulado, borde evertido, base cónica y fondo cóncavo. Con asas horizontales y simétricas, de sección plana y remache interno.

B. Vasijas

B.1 Pequeñas, de cuerpo subglobular, sin cuello. Con borde directo, labio plano o convexo y base plana. Fondo convexo. Con un asa vertical de sección plana. Altura máxima, $55 \mathrm{~mm}$; diámetro de la boca, $98 \mathrm{~mm}$; diámetro de la base, $80 \mathrm{~mm}$; altura de asa, $44 \mathrm{~mm}$; ancho de asa, $20 \mathrm{~mm}$.

B.2 Vasijas pequeñas de cuerpo subglobular. Con borde directo o invertido. Base plana y pequeña, fondo cóncavo. Con asas pequeñas en forma de mamelón, simétricas, ubicadas en el borde. Altura total, $73 \mathrm{~mm}$, ancho total, $104 \mathrm{~mm}$; alto de asas, $5 \mathrm{~mm}$; ancho de asas, $20 \mathrm{~mm}$; diámetro de la base, $40 \mathrm{~mm}$.

C. Pucos

C.1 De paredes rectas u oblicuas levemente hacia afuera. Con labio redondeado. Base plana con impronta de cestería; fondo levemente convexo.

C.2 Hemisféricos: de borde directo y reforzados; labios redondeados. Base y fondo plano, asas horizontales y simétricas. Asas de sección plana, próximas al borde. También pequeñas, en mamelón, aplicadas al borde. De diversos tamaños. Impronta de cestería en las bases. 
C.3 De paredes redondeadas y base con impronta de cestería. Línea neta de separación entre cuerpo y borde. Borde directo, reforzado y angular en coma hacia fuera. Piezas de gran tamaño. Altura total, $155 \mathrm{~mm}$; diámetro base, $50 \mathrm{~mm}$; diámetro boca, $320 \mathrm{~mm}$; altura del cuerpo, $85 \mathrm{~mm}$; altura del borde, $70 \mathrm{~mm}$.

D. Vasos

D.1 De forma cilíndrica, con paredes verticales y borde levemente evertido. Base plana y fondo convexo. Asa vertical de sección plana, aplicada con remache. Labio convexo. Altura total, $174 \mathrm{~mm}$; diámetro base, $11 \mathrm{~mm}$; diámetro boca, $135 \mathrm{~mm}$; altura de asa, $42 \mathrm{~mm}$; ancho de asa, $24 \mathrm{~mm}$.

E. Vasos: De motivos zoomorfos y antropomorfos, o combinaciones de ambos.

F. Pipas: Todos los ejemplares provistos de hornillo cilíndrico, dos patas de apoyo y rodete anular que une ambas ramas.

G. Vasos anulares: Solamente se hallaron fragmentos.

H. Ocarinas: De forma esferoidal, con orificios y decoración grabada geométrica en base a cruces y motivos escaleriformes.

I. Figurinas modeladas en arcilla, macizas y huecas. Al pastillaje.

Decoración: Técnica pintada, aplicaciones al pastillaje, grabado e inciso.

Pintada: Este tipo de decoración se observa en las ollas (A.1 y A.2). Se trata de aplicaciones de pintura postcocción en colores rojo y amarillo, dispuestos en forma irregular. Se observan simples manchones y probablemente manos en positivo.

Pastillaje: Aplicaciones presentes en varias formas de piezas. Pueden representar rodetes supraorbitarios, envolventes en la porción media del cuerpo, narices, asas en mamelón, adornos, etcétera.

Grabado: Observado en el interior de un puco hallado en CD.t.2. Ejecutado luego de la cocción. Representa una escena de lucha entre dos animales unidos a un antropomorfo en la cara opuesta.
Inciso: Es el tipo de decoración más frecuente en el grupo Las Cuevas Gris Pulido. Se ejecuta en base a líneas rectas y paralelas en las asas; o en zonas próximas a los bordes.

En los vasos antropomorfos y zoomorfos, la incisión acompaña al pastillaje en la ejecución de las cejas, nariz, boca, ojos, adornos corporales y sexo. En los hornillos de las pipas representan cruces dobles y campos geométricos que son rellenados con incisiones circulares. Muchos de estos motivos fueron rellenados con pigmentos rojo y amarillo.

\section{Tipo 2. Cerro El Dique Gris Pulido Fino}

Otros nombres: Las Cuevas Negro Pulido (Cigliano et al. 1972). Potrero Grande Gris Pulido Fino (Raffino 1972).

\section{Sitio tipo: Las Cuevas.}

Pasta: Presenta similares atributos que el tipo Las Cuevas Gris Pulido.

Superficie: Aquí es donde se observan diferencias con el tipo Las Cuevas Gris Pulido; éstas son: a) mejor acabado de las superficies, que están bruñidas en este tipo; b) espesor de las paredes menor de $8 \mathrm{~mm}$; más delgadas que el tipo anterior; c) han sido tratadas con una capa de especularita (mineral de hierro).

\section{Formas:}

A. Ollas de cuerpo subglobular, con borde directo o levemente evertido, simple y reforzado. Labio convexo y base plana. De fondo plano o apenas convexo. Sin asas. Con decoración al pastillaje en el borde y cuello. Altura total inferior a los $200 \mathrm{~mm}$.

B. Vasos de paredes verticales, base plana, fondo plano o convexo. Borde suavemente evertido. Con un asa vertical ubicada en el tercio superior de la pieza. El diámetro máximo coincide con la boca. Hay diversos tamaños, desde 120 a $180 \mathrm{~mm}$ de altura máxima; de 110 a 140 mm de diámetro de boca, y de 75 a $115 \mathrm{~mm}$ de diámetro de base.

C. Pucos similares a las variables C. 1 y C.2 del tipo Las Cuevas Gris Pulido.

D. Vasos zoomorfos y antropomorfos, similares a los descritos en el tipo Las Cuevas Gris Pulido. 
Diferenciados por mejor tratamiento de las superficies y por menor espesor de paredes.

E. Vasos anulares: Sólo se hallaron fragmentos. Describen un rodete hueco y circular. De superficies bruñidas y paredes muy finas.

Tipo 5. Las Cuevas Rojo Pulido Pintado

Otros nombres: Las Cuevas Rojo Pulido (Cigliano 1970), Potrero Grande Rojo Pulido Pintado (Raffino y Togo 1970).

\section{Sitio tipo: Las Cuevas.}

Pasta: Método manufactura: rodete.

Antiplástico: De 35 a $45 \%$ predominante limoso (menor de 62 micrones), pero con abundantes componentes de tamaño arena. Constituidos esencialmente por cuarzo generalmente límpido, de forma angulosa-subangulosa; plagioclasa de tipo oligoclasa andesina, individuos tabulares subangulosos y en estado fresco (rara vez escasamente alterados), feldespato potásico (ortoclasa y sanidina) de forma subangular y trizas vítreas limosas, subangulosas y frescas. Además hay biotita parda y verdosa y muy escaso circón, magnetita y apatita.

Color: Rojo ladrillo a corácea en su interior.

Textura: Poco porosa.

\section{Cocción: Oxidante. Dureza, 4.}

Superficies: Externa pulida, con una capa de pintura precocción roja. Interna: pulida, tratada también con pintura roja.

\section{Formas:}

Bordes directos, evertidos y reforzados (engrosados). Asas en mamelón, pequeñas, aplicadas al pastillaje. Bases planas, fondos planos o levemente convexos.

A. Ollas de rasgos similares a la variedad A.1 del tipo Las Cuevas Gris Pulido.

B. Pucos similares a las variedades C.2 y C. 3 del tipo Las Cuevas Gris Pulido.
Decoración: Técnica pintada, aplicación al pastillaje, grabada e incisa.

Pintada: Mediante la ejecución pareja en toda la pieza de una capa de color rojo diluido (monócromo rojo) sin constituir motivos.

Pastillaje: Aplicaciones de asas mamelonares pequeñas, ubicadas en el tercio superior o en los bordes de pucos.

Grabado-inciso: Ejecuciones de líneas rectas, paralelas entre sí y verticales. Se ubican en el cuello y borde de pucos de la variedad Las Cuevas Gris Pulido, C.3.

Tipo 6. Cerro El Dique Rojo Alisado

Otros nombres: Potrero Grande Rojo Alisado (Raffino 1972).

Sitio tipo: Cerro El Dique, depto. Rosario de Lerma, Salta.

Pasta: Método de manufactura: rodete.

Antiplástico: Similares atributos que el tipo Las Cuevas Rojo Pulido Pintado.

Color: Rojo ladrillo y gris en su interior.

Textura: Porosa. Dureza: 3.5 .

Cocción: Oxidante, incompleta.

Superficies: Externa e interna: alisada, sin tratamiento de pintura.

\section{Formas:}

A. Ollas subglobulares de cuerpo, con cuello estrangulado y borde evertido y engrosado. De labio convexo y base apenas insinuada y plana. Asas verticales de sección plana, con remache interno. Dimensiones: de $25 \mathrm{~mm}$ a más de altura total.

Tipo 3. Cerro El Dique Gris Externo Rojo Interno

Otros nombres: Las Cuevas Gris Externo Rojo Interno (Cigliano et al. 1972); Potrero Grande Gris Externo Rojo Interno (Raffino 1972). 
Sitio tipo: Cerro El Dique.

Pasta: Método de manufactura: rodete.

Antiplástico: Limosos muy finos y escasos arenosos (20 a 125 micrones), de 20 a $30 \%$. Compuesto por dos variedades de cuarzo, teñido y límpido en proporciones constantes; plagioclasa de tamaño limo fino a grueso, frescas y subangulosas y trizas vítreas, abundantes en la fracción limo, escasamente alteradas y angulosas. Hay abundantes y muy finas laminillas de biotita y guesas de muscovita, además de hornblenda en muy escasa proporción. Hay también escasas células vegetales compuestas por calcedonia. Plástico con menor tenor de pátina hematítica.

Color: Gris externo y rojo diluido interno, o viceversa.

Dureza: Externa: 4, interna: 3.6. Textura poco porosa.

Cocción: Las diferencias en los colores indican diferencias en el tipo de cocimiento de la pasta.

Superficie: Externa, de color gris pulida; interna, roja. Esta relación puede invertirse.

\section{Forma:}

A. Pucos de la variedad C.2 del tipo Las Cuevas Gris Pulido.

B. Ollas de las variedades A.1 y A.2 del tipo Las Cuevas Gris Pulido.

Tipo 7. Las Cuevas Tricolor (Cigliano 1970)

Otros nombres: Potrero Grande Tricolor (Raffino 1972).

Sitio tipo: Las Cuevas.

Pasta: Método de manufactura, rodete y modelado.

Antiplástico: Escaso, de 12 a $25 \%$ de arena, $75 \%$ de limo. Compuesto por cuarzo teñido (abundante) y límpido en individuos siempre menores a 125 micrones. Trizas de vidrio volcánico muy angulosos y subangulosos, fresco y medianamente alterado, de tamaño limo fino a mediano. Además escasa plagioclasa fresca de grano muy fino. E1 principal componente pesado es biotita, acompañada por lamprobolita y en escasa proporción. Plástico arcilloso y micáceo, de grano muy fino (tamaño arcillita), teñido totalmente por una pátina hematítico-limonítica.

Color: Rojo con banda interna gris.

Textura: Muy porosa.

Cocción: Oxidante. Dureza: 4.2.

Superficie: Externa e interna: castaño amarillenta, pintada o natural de la pasta; está pulida.

Forma:

A. Pucos hemiesféricos de base plana. Borde directo o levemente reforzado y evertido. Decorados interna y externamente.

B. Vasos timbales con paredes cóncavas-convexas, de base plana y un asa vertical en cinta. De borde simple.

C. Vasos cilíndricos con paredes verticales, base plana y un asa vertical en cinta.

D. Ollas subglobulares de silueta restringida, con cuello vertical, base plana y borde evertido.

E. Vasijas de cuerpo subglobular, con cuello vertical, borde evertido y base plana. Con asas verticales.

F. Vasos zoomorfos y antropomorfos ejecutados al pastillaje (modelados) con vertedera, aplicaciones $\mathrm{y}$ asas pequeñas en cinta.

Decoración: Técnica pintada en tres colores (a veces dos), aplicaciones al pastillaje.

Pintada: Con motivos ejecutados en color negro y rojo sobre fondo castaño amarillento. Se ubican generalmente en posición vertical. Se observan motivos geométricos líneales, como triángulos rectos y oblicuos, escaleras de tres peldaños, líneas horizontales que delimitan campos geométricos, líneas paralelas quebradas, formando escaleras de 
tres peldaños. Se observan también líneas paralelas verticales ubicadas en el cuello y base. También en las asas cuando existen. Se ubican en la superficie externa en los vasos cilíndricos y ollas; o en ambas en el caso de los pucos. En algunas piezas la decoración adquiere excelente factura.

En los vasos zoo y antropomorfos, la decoración es menos abstracta, representa adornos corporales o decorando apéndices (rodetes supraorbitarios, boca, ojos, etc.).

Tipo 9. Las Cuevas Corrugado (Cigliano 1970)

Otros nombres: Cerro El Dique Dígito-unguicular (Raffino y Togo 1970), Palpalá Corrugado Complicado (Dougherty 1974).

Sitio tipo: Las Cuevas.

Pasta: Método de manufactura: rodete.

Antiplástico: Plástico arcilloso color gris oscuro, rico en material orgánico, a veces de pátina limonítica. Muy escaso antiplástico (7 a 12\%) constituido por cuarzo teñido y límpido de tamaño limo a arena mediana. Vidrio volcánico en trizas gruesas y largas de tamaño arena mediana y muy fina, fresco y subanguloso. Además muy escasa proporción de biotita, hornblenda y plagioclasa.

\section{Textura: Porosa.}

\section{Color: Gris oscuro. Dureza: 4.2}

Cocción: Dispareja, tiende a oxidante, pero presenta manchones producto de la falta de oxígeno.

Superficie: Externa e interna pulidas, de tonalidades gris oscura a parda.

\section{Forma:}

Bordes: Angulares y engrosados por una capa adicional de arcilla, con labio convexo. Espesor de paredes: mayor de $8 \mathrm{~mm}$. Base: apenas insinuada y plana.

A. Pucos de paredes rectas y oblicuas, muy abiertas, cuello, borde evertido, angulares y engrosados. Labio convexo. De grandes dimensiones. Sin asas.
B. Pucos de paredes redondeadas, con cuello separado del cuerpo por punto de inflexión. Borde evertido, angular y labio engrosado y convexo. De base plana. Sin asas.

Decoración: Técnicas unguipulgar, espatular y con impronta de cestería.

1. Unguipulgar: Ejecutada mediante la impresión de la uña y el dedo pulgar, Se localiza en la zona del cuello. Son verticales u oblicuas, subparalelas entre sí. Con posterioridad se ha efectuado un alisado con el objeto de suavizar la superficie.

2. Espatular: Mediante incisiones rítmicas, trazadas en sentido oblicuo a vertical. Ejecutadas con un instrumento de punta roma. Se localizan, al igual que la técnica anterior, en el cuello de la pieza.

3. Con impronta de cestería; representada en escasa frecuencia, tal vez por el posterior pulido de la superficie, que elimina los testigos. Se ha utilizado el cesto como molde, observándose en la base las piezas preferentemente.

Tipo 8. Las Cuevas Ordinario

Otros nombres: Cerro El Dique Tosco (Raffino y Togo 1970).

\section{Sitio tipo: Las Cuevas.}

Pasta: Método de manufactura: rodete.

Antiplástico: Mediano, mediano-fino; proporción estimada, 12 a $20 \%$, compuesto básicamente por cuarzo teñido y límpido en proporciones parejas.

Textura: Porosa, con antiplástico distribuido disparejamente; con burbujas de aire.

Color: Gris pardusco, se observan manchones más obscuros.

Cocción: Oxidante, incompletamente, dispareja.

Superficies: Externa e interna de colores similares a la pasta; ambas han sido toscamente peinadas o marleadas. 
Forma:

Bordes: Evertidos, expandidos y directos.

Espesor de paredes: Más de $10 \mathrm{~mm}$.

Bases: Planas, cónicas y apenas insinuadas.

Apéndices: Asas de sección plana, aplicadas o remachadas, verticales y horizontales, ubicadas en el cuerpo o en el borde.

A. Ollas de cuerpo subglobular, silueta restringida, cuello estrangulado, borde directo o evertido, con asas simétricas horizontales o verticales, base plana apenas insinuada. Superficie externa peinada. Varios tamaños.

Decoración: Técnicas con aplicación de pintura postcocción e incisa.

1. Pintada postcocción en pigmento rojo y amarillo, se ubican en el cuerpo de las ollas.

2. Incisa ubicada en asas y cuello de las ollas. Con motivos geométricos lineales y subparalelos entre sí. Toscamente ejecutados.

Tipo 4. Las Cuevas Inciso Grabado

Otros nombres: Cerro El Dique Inciso Grabado, Potrero Grande Inciso Grabado (Raffino 1972).

Pasta: De microscopía similar a la del tipo Las Cuevas Gris Pulido.

Textura: Color, método de manufactura, cocción y dureza similares a Las Cuevas Gris Pulido. Aunque la cocción puede, en algunas piezas, ser oxidante.

\section{Forma:}

Bordes: Directos, reforzados, expandidos y angulares. Espesor de paredes: $6 \mathrm{~mm}$ a más. Bases: planas, fondo plano o levemente convexo.

A. Ollas de la variedad A.1 del tipo Las Cuevas Gris Pulido.

B. Pucos de la variedad C.1 del tipo Las Cuevas Gris Pulido.
C. Pucos de la variedad C.2 del tipo Las Cuevas Gris Pulido.

D. Pucos de la variedad C.3 del tipo Las Cuevas Gris Pulido.

E. Vasos de la variedad D.1 del tipo Las Cuevas Gris Pulido.

Decoración: Técnica: incisiones cuyo ancho varía entre 1 a $4 \mathrm{~mm}$; las profundidades máximas son de $2.5 \mathrm{~mm}$. La mayoría de las terminaciones son adelgazadas y el ancho es relativamente constante. Las aplicaciones son irregulares, a pesar que las líneas están realizadas en forma nítida. Los punteados están ejecutados con un instrumento simple, y se nota la dirección en que ha sido efectuada la punción por el arrastre de pasta. Estos puntos e incisiones son poco profundos, llegan a tener $0.5 \mathrm{~mm}$.

Grabados: Líneas finas $(0.5 \mathrm{~mm})$ de poca profundidad, ejecutadas sobre pasta de consistencia dura y con mejor acabado que la incisión.

Motivos: La decoración se ofrece en bandas, en el cuello de ollas, en el cuello, borde y asas de los pucos, también en el tercio superior de los vasos cilíndricos. En los vasos biomorfos representan diferentes rasgos faciales y adornos. Algunos de los motivos incisos-grabados han estado rellenos con pintura postcocción de color rojo y amarillo. Los motivos más frecuentes son:

1. Líneas verticales subparalelas y cortas (10 a $15 \mathrm{~mm}$ de longitud) ejecutadas a $5 \mathrm{~mm}$ de separación entre sí.

2. Líneas verticales subparalelas largas (14 a $25 \mathrm{~mm}$ de longitud), entre 5 a 9 mm de separación entre sí.

3. Zigzagueos, producidos por líneas oblicuas, dejando espacios rellenos por líneas oblicuas, irregularmente paralelas, en número de tres la mayoría de las veces, o dos en otras. En todos los casos se nota la dirección de la incisión. En dos piezas la decoración en banda, se complementa oblicuamente con incisiones cortas de 7 a $100 \mathrm{~mm}$. 
4. Líneas verticales y oblicuas que en ciertos sectores se entrecruzan, sin llegar a formar un reticulado. No hay uniformidad, inclusive da la impresión de no haber sido acabada la pieza en ese sector. Se presenta en cuellos de pucos (Las Cuevas Gris Pulido: C.3), cuerpo de piezas y sobre las asas. Ejecutados siempre con un instrumento de varios dientes.

5. Punteado en zonas, combinando con áreas rellenas de líneas paralelas. Localizadas en cuerpo y cuello de pucos y en hornillos de pipas.

6. Punteado de líneas paralelas en zigzag, complementados con un punteado en el labio de la pieza.

7. Impronta de cordelería y cestería, cuyos vestigios suelen hallarse en la base de las piezas y con menor frecuencia en sectores mal pulidos de las paredes.

8. Campos geométricos rellenos con punteado en hornillos de pipas.

9. Cruces dobles, representaciones de adornos corporales, tocados y rasgos faciales. Ejecutados sobre vasos biomorfos, vasos anulares y pipas.

Observaciones: Dentro de este tipo Las Cuevas IncisoGrabado se han agrupado las muestras pertenecientes a los tipos Las Cuevas Gris Pulido; Cerro El Dique Gris Pulido Fino, Las Cuevas Rojo Pulido Pintado y Cerro El Dique Rojo Alisado que, no obstante pertenecer a los tipos mencionados, se tomó a la decoración -incisa-grabada-, como criterio para una posterior diferenciación en este tipo.

\begin{tabular}{|c|c|c|c|c|c|c|}
\hline Tipo $\quad$ Capa & $\underset{\mathbf{~ I}}{\mathbf{0 - 0 . 2 0 ~ m}}$ & $\underset{0.20-0.40}{\text { II }}$ & $\underset{0.40-0.60}{\text { III }}$ & $\begin{array}{c}\text { IV } \\
0.60-0.80\end{array}$ & $\begin{array}{c}\mathrm{V} \\
0.80-1 \mathrm{~m}\end{array}$ & $\begin{array}{c}\text { Total } \\
\text { fragmentos }\end{array}$ \\
\hline \multirow{2}{*}{$\begin{array}{l}\text { Las Cuevas Gris } \\
\text { Pulido }\end{array}$} & 170 & 18 & 250 & 36 & 42 & 516 \\
\hline & $29.2 \%$ & $39.12 \%$ & $32.12 \%$ & $35.28 \%$ & $44.66 \%$ & \\
\hline \multirow{2}{*}{$\begin{array}{l}\text { Cerro El Dique Gris } \\
\text { Pulido Fino }\end{array}$} & 26 & - & 70 & 6 & 8 & 110 \\
\hline & $4.4 \%$ & - & $8.99 \%$ & $5.88 \%$ & $8.50 \%$ & \\
\hline \multirow{2}{*}{$\begin{array}{l}\text { Cerro El Dique Gris } \\
\text { y Rojo }\end{array}$} & 168 & 4 & 124 & 10 & 14 & 320 \\
\hline & $28.8 \%$ & $8.6 \%$ & $15.95 \%$ & $9.80 \%$ & $14.8 \%$ & \\
\hline \multirow{2}{*}{$\begin{array}{l}\text { Las Cuevas Inciso } \\
\text { Grabado }\end{array}$} & 12 & 8 & 6 & 4 & 2 & 32 \\
\hline & $2.06 \%$ & $17.3 \%$ & $0.7 \%$ & $3.9 \%$ & $2.12 \%$ & \\
\hline \multirow{2}{*}{$\begin{array}{l}\text { Las Cuevas y Cerro } \\
\text { El Dique Rojos }\end{array}$} & 102 & 4 & 146 & 12 & 10 & 274 \\
\hline & $17.5 \%$ & $8.6 \%$ & $18.76 \%$ & $11.7 \%$ & $10.6 \%$ & \\
\hline \multirow{2}{*}{ Las Cuevas Tricolor } & 4 & 2 & 26 & 6 & 6 & 44 \\
\hline & $0.6 \%$ & $4.34 \%$ & $3.34 \%$ & $5.88 \%$ & $6.38 \%$ & \\
\hline \multirow{2}{*}{$\begin{array}{l}\text { Las Cuevas } \\
\text { Ordinario }\end{array}$} & 42 & 10 & 154 & 28 & 12 & 246 \\
\hline & $15.8 \%$ & $21.73 \%$ & $19.78 \%$ & $27.44 \%$ & $12.46 \%$ & \\
\hline \multirow{2}{*}{$\begin{array}{l}\text { Las Cuevas } \\
\text { Corrugado }\end{array}$} & 6 & - & - & - & - & 6 \\
\hline & $1.3 \%$ & - & - & - & - & \\
\hline \multirow{2}{*}{ Totales } & 580 & 46 & 776 & 102 & 94 & 1548 \\
\hline & $99.76 \%$ & $99.98 \%$ & $99.71 \%$ & $99.96 \%$ & $99.96 \%$ & \\
\hline
\end{tabular}

Cuadro 4. Estratigrafía sobre PG.s.I; PG.s.II; PG.s.III y PG.s.IV. 


\begin{tabular}{|c|c|c|c|c|c|c|}
\hline Tipo $\quad$ Capa & $\begin{array}{c}\text { I } \\
0-0.20 \mathrm{~m}\end{array}$ & $\underset{\text { II }}{0.20-0.40}$ & $\begin{array}{c}\text { III } \\
0.40-0.60\end{array}$ & $\begin{array}{c}\text { IV } \\
0.60-0.80\end{array}$ & $\begin{array}{c}\mathrm{V} \\
0.80-1 \mathrm{~m}\end{array}$ & $\begin{array}{c}\text { Total } \\
\text { fragmentos }\end{array}$ \\
\hline \multirow{2}{*}{$\begin{array}{l}\text { Las Cuevas Gris } \\
\text { Pulido }\end{array}$} & 8 & 66 & 142 & 24 & - & 240 \\
\hline & $28.56 \%$ & $39.27 \%$ & $41.46 \%$ & $35.29 \%$ & - & \\
\hline \multirow{2}{*}{$\begin{array}{l}\text { Cerro El Dique Gris } \\
\text { Pulido Fino }\end{array}$} & - & 20 & 24 & 6 & - & 50 \\
\hline & & $11.9 \%$ & $7 \%$ & $8.82 \%$ & - & \\
\hline \multirow{2}{*}{$\begin{array}{l}\text { Cerro El Dique Gris } \\
\text { y Rojo }\end{array}$} & 8 & 22 & 46 & 6 & - & 82 \\
\hline & $28.5 \%$ & $13.4 \%$ & $13.4 \%$ & $8.82 \%$ & - & \\
\hline \multirow{2}{*}{$\begin{array}{l}\text { Las Cuevas Inciso } \\
\text { Grabado }\end{array}$} & - & - & 8 & - & - & 8 \\
\hline & - & - & $2.33 \%$ & - & - & \\
\hline \multirow{2}{*}{$\begin{array}{l}\text { Las Cuevas y Cerro } \\
\text { El Dique Rojos }\end{array}$} & 4 & 36 & 66 & 18 & - & 124 \\
\hline & $14.2 \%$ & $21.4 \%$. & $19.2 \%$ & $26.4 \%$ & - & \\
\hline Las Cuevas Tricolor & - & - & - & - & - & \\
\hline \multirow{2}{*}{$\begin{array}{l}\text { Las Cuevas } \\
\text { Ordinario }\end{array}$} & 4 & 24 & 42 & 12 & - & 82 \\
\hline & $14.2 \%$ & $14.2 \%$ & $12.2 \%$ & $17.6 \%$ & - & \\
\hline $\begin{array}{l}\text { Las Cuevas } \\
\text { Corrugado }\end{array}$ & 4 & - & 4 & 2 & - & 10 \\
\hline \multirow{2}{*}{ Totales } & 28 & 168 & 332 & 68 & - & 596 \\
\hline & $99.98 \%$ & $99.96 \%$ & $99.98 \%$ & $99.98 \%$ & - & \\
\hline
\end{tabular}

Cuadro 5. Cerro El Dique, estratigrafía sobre CD.s.17 y CD.s.18.

\begin{tabular}{|c|c|c|c|c|c|c|c|c|}
\hline Proc. & $\begin{array}{c}\text { Las } \\
\text { Cuevas } \\
\text { Gris } \\
\text { Pulido }\end{array}$ & $\begin{array}{c}\text { Cerro El } \\
\text { Dique Gris } \\
\text { Pulido } \\
\text { Fino }\end{array}$ & $\begin{array}{c}\text { Cerro El } \\
\text { Dique Gris } \\
\text { y Rojo }\end{array}$ & $\begin{array}{c}\text { Las } \\
\text { Cuevas } \\
\text { Inciso } \\
\text { Grabado }\end{array}$ & $\begin{array}{c}\text { Las } \\
\text { Cuevas } \\
\text { Rojo }\end{array}$ & $\begin{array}{c}\text { Las } \\
\text { Cuevas } \\
\text { Tricolor }\end{array}$ & $\begin{array}{c}\text { Las } \\
\text { Cuevas } \\
\text { Ordinario }\end{array}$ & $\begin{array}{c}\text { Las } \\
\text { Cuevas } \\
\text { Corrugado }\end{array}$ \\
\hline CD-t.1 & $\mathrm{X}$ & $\mathrm{X}$ & & & & & & \\
\hline CD-t.2 & $X$ & & & & & & & \\
\hline CD-t.3 & XX & & & & & $\mathrm{XX}$ & & \\
\hline CD-t.4 & XXXX & $\mathrm{X}$ & & & & & & \\
\hline CD-t.6 & XX & & & & & & & \\
\hline CD-t.7 & XXX & & XX & & & & & \\
\hline CD-t.10 & XX & $\mathrm{X}$ & & & & & & \\
\hline CD-t.11 & & & & $X$ & & & & \\
\hline LC-t.1 & $X$ & & & & & & & \\
\hline LC-t.2 & & $X$ & & & & & & \\
\hline LC-t.3 & $X$ & & & & & & & \\
\hline LC-t.4 & & & & & & & $X$ & \\
\hline PG-t.1 & & & $X$ & & & $\mathrm{X}$ & & \\
\hline LE-t.1 & $X$ & $\mathrm{X}$ & & & & & & \\
\hline LCa-t.1 & $\mathrm{X}$ & $\mathrm{X}$ & & & & & & \\
\hline LM-t.1 & & $X$ & & & & & & \\
\hline
\end{tabular}

Cuadro 6. Tipos de alfarería presentes en la funebria: x: presencia por unidad; Cerro El Dique (CD); Las Cuevas (LC); Potrero Grande (PG); La Encrucijada (LE); Las Capillas (LCa); La Mina (LM). 


\begin{tabular}{|c|c|c|c|c|c|c|c|}
\hline Proc. Forma & $\begin{array}{c}\text { Pucos } \\
\text { hemisf. }\end{array}$ & $\begin{array}{l}\text { Pucos } \\
\text { p/vert. }\end{array}$ & Vasos cilínd. & Ollas subgl. & $\begin{array}{c}\text { Vasos } \\
\text { antrop. }\end{array}$ & Vasos zoom. & Pipas \\
\hline CD-t.1 & $\mathrm{X}$ & & & & & $\mathrm{X}$ & \\
\hline CD-t.2 & $\mathrm{X}$ & & & & & & \\
\hline CD-t.3 & & & $\mathrm{XX}$ & $\mathrm{XX}$ & & & $\mathrm{X}$ \\
\hline CD-t.4 & & & $\mathrm{XXX}$ & & & & $\mathrm{XX}$ \\
\hline CD-t.6 & $\mathrm{X}$ & & $\mathrm{X}$ & $\mathrm{X}$ & & & \\
\hline CD-t.10 & & & $\mathrm{X}$ & $\mathrm{XX}$ & & & \\
\hline CD-t.11 & & & & & & & $\mathrm{X}$ \\
\hline LC-t.1 & & $\mathrm{X}$ & & & & & \\
\hline LC-t.2 & & & & & $\mathrm{X}$ & & \\
\hline LC-t.3 & & & & & $\mathrm{X}$ & & $\mathrm{X}$ \\
\hline LC-t.4 & & & & $\mathrm{X}$ & & & \\
\hline PG-t.1 & & & & $X$ & & $\mathrm{X}$ & \\
\hline LE-t.1 & & & & $\mathrm{X}$ & $\mathrm{X}$ & & \\
\hline LCa-t.1 & X & $\mathrm{X}$ & & & & & \\
\hline LM-t.1 & & & & & $\mathrm{X}$ & & \\
\hline
\end{tabular}

Cuadro 7. Formas de la alfarería presentes en la funebria.

b) Metalurgia. La manufactura sobre los metales fue sin fundición, por la técnica del martillado en frío sobre metales en estado natural. Los más utilizados fueron el oro, cobre, galena y plata, especialmente el primero de los nombrados. Los utensilios más comunes son los collares, tiaras, brazaletes, muñequeras, anillos, cinceles, cucharas, espejos de galena, placas circulares con agujeros para colgar y placas grabadas. Fueron halladas también gruesas placas de oro, de forma circular y de hasta $150 \mathrm{~mm}$ de diámetro y $5 \mathrm{~mm}$ de espesor.

Los adornos en oro presentan motivos decorativos cincelados, a la manera de rectángulos, rombos, triángulos y escaleras de tres peldaños. Han sido exquisitamente ejecutados, rellenándose el motivo con pigmento rojo y amarillo (similar resolución decorativa que la de la alfarería incisa grabada). Uno de los brazaletes presenta una decoración en relieve de una cabeza antropomorfa provista de tocado, ofreciendo similares rasgos faciales a los que se observan en los vasos de la cerámica. Fue posteriormente rellenada de pigmento rojo.

Los análisis mineralógicos sobre el instrumental de cobre (anillo, muñequeras y cinceles) permitieron comprobar que estuvieron trabajados también sin fundición, sobre cobre en estado natural $(90 \%$ de cobre nativo y $10 \%$ de cuprita y carbonatos de cobre). El anillo no fue soldado, sino que su unión se efectuó por superposición por martillado.

Los espejos de galena fueron efectuados mediante un excelente pulimento del metal. Son de forma cuadrangular y poseen perforaciones para ser utilizados como colgantes. Carecen de decoración.

El trabajo sobre la plata es más escaso, sólo fueron halladas dos pequeñas placas con incisiones geométricas. Es muy frecuente en los ajuares de la funebria la combinación de placas de oro con cuentas cilíndricas de malaquita, azurita, hueso y fichas de valvas de caracoles terrestres; todos ellos formando collares de excelente factura. La utilización de todos estos adornos de metal se ha extendido con seguridad a lo artesanal-ceremonial. Con excepción del anillo y cincel fragmentado de cobre, hallados ambos en depósitos de basura, el resto de las piezas (18 en total) proceden de ajuares funerarios.

c) Piedra. La piedra ha sido una de las materias primas más requeridas, tanto en las tecnologías de producción como en las artesanales; trabajada por medio de percusión, presión y pulimento. Ya fue 
considerado que la arquitectura de las aldeas tuvo en la piedra su material básico. Entre las tecnologías muebles su lugar es también destacado; los elementos vinculados hacia la economía son los morteros cóncavos (de gran variedad y mucho desgaste por el uso), los molinos planos (de hasta $0.80 \mathrm{~m}$ de largo), las manos pequeñas bifaciales (molienda por percusión) y monofaciales grandes (molienda por presión); las hachas de sección plana, con garganta y huellas de uso en tareas rústicas (agricultura). Muchos de los morteros se hallaron totalmente desgastados, formando parte de las paredes de los recintos. Otros instrumentos líticos relacionados con la economía son las torteras circulares para textilería. Halláronse también puntas de proyectil sobre obsidiana y cuarcita, de tamaño pequeño y de dos tipos: con pedúnculo (tipo más antiguo estratigráficamente) y otro más reciente, con base escotada. Otros instrumentos hallados son las piedras bolas arrojadizas (para honda) de forma ovoide y circular; los platos y fuentes de forma plana o levemente cóncavos y con rebordes; las tazas; los sopladores para fuego o pipas rectas de excelente factura; los morteros y manos pequeñas para moler pintura (presentan vestigios de pigmento rojo y amarillo); sobadores para cuero, cascanueces, cuchillos dentados sobre pizarra, percutores, raspadores, raederas, núcleos y lascas de obsidiana, cuarcita y basaltos.

Es indudable el destino artesanal-ceremonial de algunos de estos artefactos, entre ellos los recipientes pulidos, morteros para pintura, así como algunas hachas de sección circular de excelente factura en el pulimento. Hacia el mismo rol relacionamos las placas grabadas y silbatos de piedra de siete notas; ambos con decoración grabada de motivos geométricos y escaleriformes. La misma posibilidad ofrecen las pipas, los sopladores rectos (vinculados posiblemente con el cocimiento de la cerámica) y las ocarinas esféricas. Todos éstos pueden presentar grabados de motivos geométricos con diseño similar a la ocarina o las pipas.

La escultura lítica está presente en forma de ídolos fálicos de los cuales se han hallado dos ejemplares, uno en Cerro El Dique y otro en Las Capillas. Ambos son bastante similares, poseen $0.60 \mathrm{~m}$ de largo y $0.20 \mathrm{~m}$ de diámetro, de forma cilíndrica. El aquí reproducido fue pulido de tal forma que se marcan las diferencias entre la cabeza y el cuerpo fálico. La decoración se efectuó mediante gruesas incisiones por presión. El motivo expuesto es una cruz, presente en los dos ejemplares.

Finalmente, entre los instrumentos líticos deben considerarse las innumerables cuentas para collar, magníficamente elaboradas sobre azurita y malaquita (las hay también sobre hueso y caracol). Se las halló abundantemente en los ajuares funerarios.

d) Cordelería, cestería y afines. Los hallazgos de esta naturaleza no han sido frecuentes, debido a que sobre su conservación ha incidido el hecho de tratarse de sitios al aire libre, así como el desafortunado detalle que la mayoría de las tumbas están a mucha profundidad, dentro de una capa de caliza que ha actuado como acelerador en la destrucción de los materiales perecibles. La cordelería utilizó como materia prima las fibras vegetales (pasto cortadera) que abunda en las playas de ríos, y animal (camélido). Se han hallado cordeles de uno y dos cabos, de color natural y también teñidos con pigmento rojo. En uno de estos hallazgos efectuado en el basural CD.U.H.4, se comprobó la asociación de cordelería trenzada de dos cabos, teñido con pigmento rojo y atada a un palillo de madera.

Otros indicadores de actividades textiles son las torteras circulares, elaboradas en cerámica gris, roja y en piedra. Así como palillos que han formado juntamente con las torteras, el huso para hilar.

También es poco frecuente el hallazgo de cuero, se remite a un par de trozos obtenidos en uno de los basurales de Potrero Grande, PG., s.II. Pertenecían a cuero y pelo de camélido.

La cestería aparece bien evidenciada en las improntas en negativo de la alfarería, especialmente en las bases. Se la ha hallado también fragmentariamente en Cerro El Dique (CD.U.H.2) en forma de fragmentos de cestos elaborados en fibra vegetal (probablemente pasto cortadera), construidos por enrollados en espiral, aparentemente correspondían a cestos de forma esférica, similares a los pucos de la cerámica.

Otro elemento de origen vegetal utilizado como recipiente, hallado fragmentariamente, son las calabazas (Lageneria sp.). Carecen de decoración; en su interior contenían restos orgánicos no identificados. 
e) Huesos y moluscos. Entre los utensilios de hueso se cuentan los punzones, espátulas, agujas, tubos, silbatos y secciones de tibias y huesos largos de camélidos provistos de pulimento y decoración mediante incisiones rectas. Los silbatos de hueso han sido identificados como tales por constar de dos pequeños orificios en ambos extremos del tubo; este último de forma cilíndrica. Otros tubos más pequeños, han sido utilizados, luego de su pulimento, como cuentas de collar, conjuntamente con la piedra y el metal. Otras extremidades de camélidos parecen haberse utilizado como adornos colgantes, puesto que presentan orificios.

Los instrumentos trabajados sobre moluscos de origen terrestre, consisten en fichas o placas circulares muy pulidas, algunas de ellas provistas de orificios. Se halló también un fragmento de molusco con restos de pigmento rojo en su interior.

f) Madera. Sus hallazgos fueron poco frecuentes, provienen de habitaciones, patios y basurales. La madera parece haber sido utilizada para usos domésticos; su registro está ausente en funebria. En los pisos de las habitaciones de Cerro El Dique, se exhumaron trozos de madera carbonizada, probablemente vinculados con el techo. En los basurales el registro fue de madera de cardón, palillos diversos, astiles, palos con cavidades para hacer fuego y palillos asociados con cordelería.

\section{Funebria}

En las seis aldeas se han exhumado una cantidad de 16 tumbas, cifra muy significativa, teniendo en cuenta la poca frecuencia de estos hallazgos en el Noroeste Argentino para el período. A los rasgos apuntados previamente, referentes a la arquitectura de las tumbas para adultos, debemos adicionar algunos más, a saber:

1. Las tumbas pueden alojarse debajo del piso de patios, o bien diseminadas en los faldeos de los cerros vecinos a las aldeas.

2. Las tumbas para adultos son individuales.

3. La posición de los esqueletos es genuflexa, decúbito lateral. Cuando el estado de conservación lo permitió, se observó una orientación del cráneo hacia el norte. Los cráneos presentan deformación artificial de tipo tabular oblicua.

4. Los párvulos fueron inhumados en urnas. Hay muy poca cantidad.

5. Algunos de los ajuares funerarios sugieren la posible función y jerarquía que desempeñó el individuo en vida.

Inventario de las tumbas

$C D$-t.1: Ubicada a $0.50 \mathrm{~m}$ por debajo del piso de CD.U.H.4. De forma cilíndrica y $0.85 \mathrm{~m}$ de diámetro. Con tapa de lajas. Contenía un esqueleto de adulto genuflexo y decúbito lateral en mal estado. El ajuar estaba compuesto por un vaso antropomorfo Cerro El Dique Gris Pulido fino, con dos apéndices, uno zoomorfo y otro en vertedera. Dimensiones: altura, $107 \mathrm{~mm}$; diám. anteroposterior, $119 \mathrm{~mm}$; diám. transvero, $95 \mathrm{~mm}$. Una segunda pieza era un puco tipo Las Cuevas Gris Pulido, variedad C.2. Dimensiones: altura, $57 \mathrm{~mm}$; diám., base, $60 \mathrm{~mm}$; diám. boca, $152 \mathrm{~mm}$.

CD-t.2: Ubicada a $1,50 \mathrm{~m}$ al oeste de la anterior y a $1 \mathrm{~m}$ por debajo del piso de CD.U.H.4. De forma cilíndrica, con techo de lajas. Contenía un esqueleto en posición genuflexa en mal estado. El ajuar constaba sólo de una pieza cerámica: un puco hemisférico tipo Las Cuevas Gris Pulido; variedad C.2. Dimensiones: altura, $105 \mathrm{~mm}$; diám. base, $75 \mathrm{~mm}$; diám. boca, $278 \mathrm{~mm}$.

$C D$-t.3: Ubicada a $2 \mathrm{~m}$ al sur de CD-t. 2 y a $1 \mathrm{~m}$ por debajo del piso de CD.U.H.4. De forma cilíndrica, diámetro de $0.90 \mathrm{~m}$ y tapa de lajas. Contenía un esqueleto en posición genuflexa y decúbito lateral, en mal estado. El cráneo con deformación tabular oblicua. El ajuar estaba compuesto por siete piezas, todas de excelente factura: un vaso cilíndrico tipo Las Cuevas Tricolor, variedad D.1. Dimensiones: altura, $130 \mathrm{~mm}$; diám. base, $75 \mathrm{~mm}$; diám. boca, $102 \mathrm{~mm}$; una olla subglobular tipo Las Cuevas Tricolor, variedad A.1. Dimensiones: altura cuerpo, $160 \mathrm{~mm}$; altura cuello, $47 \mathrm{~mm}$; diám. base, $85 \mathrm{~mm}$; diám. cuerpo, $180 \mathrm{~mm}$; diám. boca, $85 \mathrm{~mm}$, un hornillo de pipa (fragmento) en cerámica gris con aplicación zoomorfa y rellena de pigmento rojo. 
Vaso cilíndrico tipo Las Cuevas Gris Pulido, variedad D.1 (fragmento).

Diadema de oro, formada por cuatro segmentos. Está decorada con grabados geométricos, los cuales fueron pintados en color rojo. Dimensiones: largo, $166 \mathrm{~mm}$; altura, $28 \mathrm{~mm}$; peso, $20 \mathrm{gr}$.

Espejo de galena de forma cuadrangular, con orificio para colgar. Dimensiones: $45 \mathrm{~mm}$ y $37 \mathrm{~mm}$ de lado; espesor, $4 \mathrm{~mm}$; peso, $200 \mathrm{gr}$.

Olla subglobular tipo Las Cuevas Gris Pulido, variedad A.1 (fragmento). Estaba depositada sobre la tapa de lajas de la tumba.

CD-t.4: Ubicada a $1 \mathrm{~m}$ al norte de CD-t. 1 y a $1.50 \mathrm{~m}$ por debajo del piso de CD.U.H.4. De forma cilíndrica y tapa de lajas de $0.30 \mathrm{~m}$ de espesor. Diámetro de $0.50 \mathrm{~m}$. Contenía material orgánico en pésimo estado de conservación. El ajuar funerario estaba compuesto por 10 piezas.

Pipa en cerámica Gris Pulida, variedad F (fragmento). El hornillo con decoración grabada a la manera de cruces dobles. Dimensiones: largo rama horiz., $155 \mathrm{~mm}$; altura de apoyo, $4 \mathrm{~mm}$; diám. rama vert., 34 mm; diám. ram. horiz., $23 \mathrm{~mm}$.

Vaso cilíndrico tipo Las Cuevas Gris Pulido, variedad D.1. Presenta restos de pintura amarilla postcocción. Dimensiones: altura, $85 \mathrm{~mm}$; diám. base, $100 \mathrm{~mm}$; diám. boca, $115 \mathrm{~mm}$.

Vaso cilíndrico tipo Cerro El Dique Gris Pulido Fino, variedad B. Dimensiones: altura, $123 \mathrm{~mm}$; diám. base, $75 \mathrm{~mm}$; diám. boca, $100 \mathrm{~mm}$.

Vaso cilíndrico tipo Las Cuevas Gris Pulido, variedad D.1. Dimensiones: altura, $180 \mathrm{~mm}$; diám. base. $90 \mathrm{~mm}$; diám. boca, $135 \mathrm{~mm}$.

Pipa de cerámica Gris Pulida (fragmento), sin decorar. Dimensiones: altura rama vert., $220 \mathrm{~mm}$; diám. rama vert., $44 \mathrm{~mm}$; altura de apoyo, $8 \mathrm{~mm}$.

Además se hallaron cinco cuentas de collar sobre azurita, de forma cilíndrica, de $4 \mathrm{~mm}$ de diámetro y $5 \mathrm{~mm}$ de largo cada una.
$C D$-t.6: Ubicada en el centro de CD.U.H.4, a 1.80 $\mathrm{m}$ de profundidad. Forma cilíndrica, con diámetro de $0.65 \mathrm{~m}$ y tapa de lajas. Restos óseos muy destruidos de un adulto y también un infante depositado en el interior de un puco. El ajuar funerario estaba compuesto por dos piezas:

Vaso cilíndrico del tipo Las Cuevas Gris Pulido, variedad D.1. Dimensiones: altura, $64 \mathrm{~mm}$; diám. base, $84 \mathrm{~mm}$; diám. boca, $98 \mathrm{~mm}$; altura asa, $45 \mathrm{~mm}$; ancho de asa, $20 \mathrm{~mm}$.

Puco hemisférico tipo Las Cuevas Gris Pulido, variedad C.2. Dimensiones: altura, 106 mm; diám. base, $70 \mathrm{~mm}$; diám. boca, $202 \mathrm{~mm}$.

C.D-t.7: Ubicada a $2.50 \mathrm{~m}$ al oeste de la anterior y a $1.70 \mathrm{~m}$ de profundidad. De forma cilíndrica y techo de lajas, de $0.55 \mathrm{~m}$ de diámetro. El ajuar integrado por cuatro piezas de cerámica:

Puco hemisférico tipo Las Cuevas Gris Pulido, variedad C.2. Dimensiones: altura, $120 \mathrm{~mm}$; diám. base, $80 \mathrm{~mm}$; diám. boca, $230 \mathrm{~mm}$.

Puco hemisférico tipo Las Cuevas Gris Pulido, variedad C.2. Dimensiones: altura, $73 \mathrm{~mm}$; diám. base, $32 \mathrm{~mm}$; diám. boca, $98 \mathrm{~mm}$. Contenía materia orgánica y restos óseos de camélido.

Vaso cilíndrico tipo Las Cuevas Gris Pulido, variedad D.1 con restos de pintura postcocción amarilla. Dimensiones: altura, $160 \mathrm{~mm}$; diám. base, $80 \mathrm{~mm}$; diám. boca, $120 \mathrm{~mm}$.

Olla subglobular tipo Cerro El Dique Gris Exterior, Rojo Interior, variedad B (fragmento).

$C D$-t.10: Ubicada en el centro y por debajo del piso del patio CD.U.H.1, a $1.50 \mathrm{~m}$ de profundidad. De forma cilíndrica, con techo de lajas y $0.65 \mathrm{~m}$ de diámetro. Contenía un esqueleto completo en posición genuflexa, decúbito lateral izquierdo. Individuo de sexo femenino, con cráneo con deformación tabular oblicua y orientado hacia el norte. A la altura de la boca se halló un vaso pequeño con huellas de líquidos cadavéricos. El ajuar estaba compuesto por:

Olla subglobular de tipo Las Cuevas Gris Pulido, variedad A.1. Dimensiones: altura, 490 mm; diám. 
boca, $145 \mathrm{~mm}$; diám. cuerpo, $270 \mathrm{~mm}$. de base indiferenciada; un vaso pequeño tipo Cerro El Dique Gris Pulido Fino, variedad B. Dimensiones: altura, $65 \mathrm{~mm}$; diám. boca, $115 \mathrm{~mm}$; diám. base, $55 \mathrm{~mm}$; una olla subglobular pequeña, tipo Cerro El Dique Gris Pulido Fino, variedad A, con restos de pintura postcocción amarilla. Dimensiones: altura, $146 \mathrm{~mm}$; diám. base, $70 \mathrm{~mm}$ (fragmento); un hacha de piedra pulida, con cuello completo y base escotada por pulimento. Presenta la extremidad distal fragmentada.

CD-t.11: Fue hallada a $3 \mathrm{~m}$ al sur de CD.U.H.2; de forma cilíndrica y techo de lajas. Contenía un esqueleto de adulto en posición genuflexa, decúbito lateral. Cráneo deformado artificialmente en mal estado. El ajuar se componía de un brazalete de oro, en uno de sus extremos una máscara antropomorfa con magnífico tocado, ojos, nariz y boca insinuados. El grabado relleno con pigmento rojo. Dimensiones: diám. $65 \mathrm{~mm}$; ancho, $25 \mathrm{~mm}$; peso, $38 \mathrm{gr}$; una pipa en cerámica tipo Las Cuevas Tricolor (fondo castaño amarillento) con decoración incisa formando dos campos geométricos opuestos y rellenos con incisiones de puntos. El hornillo es cilíndrico, sobre él se ejecutó un zoomorfo. Dimensiones: ram. horiz., $250 \mathrm{~mm}$; diám., $35 \mathrm{~mm}$. Rama vert.: largo, $165 \mathrm{~mm}$ (fragmento); diám., $32 \mathrm{~mm}$. Patas de apoyo: alto, $12 \mathrm{~mm}$; de forma cónica. También se hallaron 30 cuentas de collar de ma-laquita y azurita y hueso.

PG-t.1: La única hallada en Potrero Grande, estaba ubicada a $300 \mathrm{~m}$ al sur de la aldea. De forma cilíndrica, con techo de lajas. Contenía un esqueleto de adulto totalmente destruido. El ajuar estaba integrado por:

Un vaso zooantropomorfo excepcional del tipo Las Cuevas Tricolor, variedad F. Presenta decoración pintada y modelada. La rama vertical es una vertedera decorada con un motivo antropomorfo. Sobre la base de la vertedera hay dos pequeñas asas horizontales y simétricas. La rama horizontal es un ofidio con cabeza y cuerpo realista pintado a tres colores. Dimensiones: ram. horiz., $190 \mathrm{~mm}$; ancho, $12 \mathrm{~mm}$. Ram. vert., $70 \mathrm{~mm}$; ancho, $45 \mathrm{~mm}$. Asas: alto, $12 \mathrm{~mm}$; ancho $20 \mathrm{~mm}$.
Olla subglobular tipo Las Cuevas Ordinario, variedad A. Dimensiones: altura, $800 \mathrm{~mm}$; diám. boca, $220 \mathrm{~mm}$; diám. base, $170 \mathrm{~mm}$; diám. máx. cuerpo, $490 \mathrm{~mm}$.

LE-t.1: Hallada accidentalmente a $1.50 \mathrm{~m}$ de profundidad. Contenía un individuo adulto genuflexo con cráneo deformado artificialmente en mal estado. El ajuar se componía de dos piezas cerámicas y cuentas de collar; una olla subglobular pequeña del tipo Cerro El Dique Gris Pulido Fino, variedad A (fragmento), una máscara antropomorfa sobre alfarería Las Cuevas Gris Pulido, de ojos circulares y provista de adornos labiales, sobre la cara una especie de tocado o gorro. Todo se encuentra ejecutado al pastillaje (fragmento).

LC-a.1: Hallada accidentalmente por un agricultor de la zona. No hay referencias de esqueleto. El ajuar se compone por un puco del tipo Las Cuevas Gris Pulido, variedad C.3. Con asas simétricas y horizontales, aplicadas al borde y con ocho incisiones paralelas entre sí y perpendiculares al borde; un plato de piedra pulida con reborde. Dimensiones: altura, $7 \mathrm{~mm}$; lado mayor, $20 \mathrm{~mm}$; de forma rectangular; un vaso de tipo Las Cuevas Inciso Grabado, variedad C. Con decoración geométrica de motivos triangulares.

LC-t.1: Ubicada por debajo de un recinto circular grande. De forma cilíndrica, con techo de lajas. Diám. de $1.50 \mathrm{~m}$; altura, $0.30 \mathrm{~m}$. Proporcionó restos de un individuo adulto muy destruidos. El ajuar estaba compuesto por una sola pieza: un puco tipo Las Cuevas Gris Pulido, variedad C.1. Dimensiones: altura, $80 \mathrm{~mm}$; diám. base, $70 \mathrm{~mm}$; diám. boca, $128 \mathrm{~mm}$.

LC-t.2: Ubicada dentro del montículo oeste, debajo del piso de un recinto circular grande. Posee techo de lajas y forma cilíndrica. Contenía pocos restos óseos muy destruidos. El ajuar estaba compuesto por una sola pieza: un vaso antropomorfo de excepcional factura de tipo Cerro El Dique Gris Pulido Fino, variedad D. Se trata de una cabeza deformada artificialmente, provista de cejas, nariz en trazo continuo; ojos con párpados cerrados, boca abierta y orejas con orificios para adornos. De la barbilla parte un asa circular de sección circular. Dimensiones: altura, $104 \mathrm{~mm}$; altura asas, $25 \mathrm{~mm}$; diám. trans. máx., 
$78 \mathrm{~mm}$; diám. asas, $32 \mathrm{~mm}$; diám. boca, $24 \mathrm{~mm}$; diám. ant. post. máx., $60 \mathrm{~mm}$.

LC-t.3: Ubicada dentro del montículo norte de Las Cuevas, por debajo de un basural y un recinto circular (tres unidades arquitectónicas superpuestas). Poseía techo de lajas. El material orgánico estaba muy mezclado con los elementos caídos desde el basural. El ajuar se integraba por: un hacha de piedra pulida con cuello completo; un lote de artefactos ligados con la confección de la alfarería, a saber: conjunto de manos de moler con restos de pigmento rojo y amarillo. Conjunto de piezas de arcilla modelada y cruda, entre ellos una pieza zoomorfa u ofidio; la pieza está decorada con incisiones. Un vaso efigie en cerámica gris pulida (fragmento). Una placa de caracol (pulidor). Un fragmento de mica con perforación. Un recipiente de molusco con el interior lleno de ocre (depósito de pintura). Un mortero pequeño (para pintura) con huellas de pigmento. Un fragmento de pipa en cerámica. Una mano de mortero con pigmento rojo (asociada al mortero). Restos varios de artefactos de piedra, entre ellos, algunas puntas de proyectil de obsidiana.

LC-t.4: Ubicada por debajo del piso del recinto LC.U.H.3. Se trató de una inhumación de párvulo en urna. La urna en alfarería Las Cuevas Ordinario, variedad A.3 de Las Cuevas Gris Pulido (con base cónica y asas verticales simétricas). Dimensiones: altura, $530 \mathrm{~mm}$; diám. trans. máx., $280 \mathrm{~mm}$. Con dos asas verticales que parten del borde de la pieza y de sección plana (en cinta). Cuello estrangulado, borde evertido y fondo cóncavo.

LM-t.1: Fue hallada accidentalmente por un agricultor. Con techo de lajas, no se obtuvieron otras referencias del contenido orgánico. Estaba ubicada por debajo de un pequeño basural, en terrenos reutilizados por los pobladores actuales. En el mismo lugar se aprecian huellas de posibles recintos asociados a la tumba. El ajuar funerario estaba compuesto por dos piezas: un vaso antropomorfo tipo Cerro El Dique Gris Pulido Fino, variedad D. Representa a un individuo de sexo femenino, con ambos brazos recogidos sobre el vientre, de ojos circulares y un adorno colgante (collar). De la cabeza parte una vertedera. Posee un asa vertical opuesta a la figura, de sección plana (en cinta). Altura, 162 mm; diám. máx. $104 \mathrm{~mm}$; diám. boca, $54 \mathrm{~mm}$; altura de asa, $39 \mathrm{~mm}$; ancho de asa, $26 \mathrm{~mm}$.

\section{Modelo económico y patrón de poblamiento}

Sin llegar a ser numerosos, los indicadores del registro arqueológico permiten formular inferencias sobre la economía de las aldeas formativas inferiores de la quebrada del Toro. Asimismo, con el modelo económico es factible interrelacionar otros aspectos de la cultura, como el patrón de poblamiento y densidad de población, los cuales son relativamente calculados.

Los restos de tecnologías de producción y materias primas exhumadas permiten componer un modelo económico sobre la base de la ganadería del camélido, la agricultura y el aporte de la caza de otras especies. Los recursos energéticos primordiales han sido obtenidos a partir del camélido; esto es inmediatamente deducido cuando se analizan los basurales excavados, donde los restos orgánicos del complejo llama-guanaco abarcan entre un 65 a $82 \%$ de las muestras (ver Apéndice). Sobre una muestra de 105 esqueletos exhumados en Cerro El Dique, Potrero Grande y Las Cuevas, 74 de ellos corresponden al complejo llama-guanaco.

Los indicios de la apertura del proceso de domesticación de la llama comienzan a insinuarse ya en el Arcaico de Humahuaca (Fernández Distel 1974: 117) por la presencia de individuos jóvenes de camélidos con asociación cultural. De modo tal que no es improbable suponer que este proceso de domesticación pudo tomar cuerpo pleno durante el Formativo. De la gran cantidad de restos orgánicos de llama-guanaco hallados en la quebrada del Toro (en basurales, habitaciones, patios y depósitos) se deduce su importancia económica, la cual sobrepasaría a los recursos agrícolas en relación de 2 a 1 . Asimismo, la existencia de actividades artesanales ligadas a la llama, como la textilería y cordelería, son indicios probatorios de una actividad ganadera.

Quedan, no obstante, como contrapartida, dos aspectos no totalmente resueltos, uno de ellos proviene de las escasas evidencias de corrales para el encierro de llamas. Aunque es posible que algunos de los recintos circulares grandes (p.e., Cerro El Dique) hayan sido utilizados como corrales, y que la posterior utilización del guano como combustible y en 


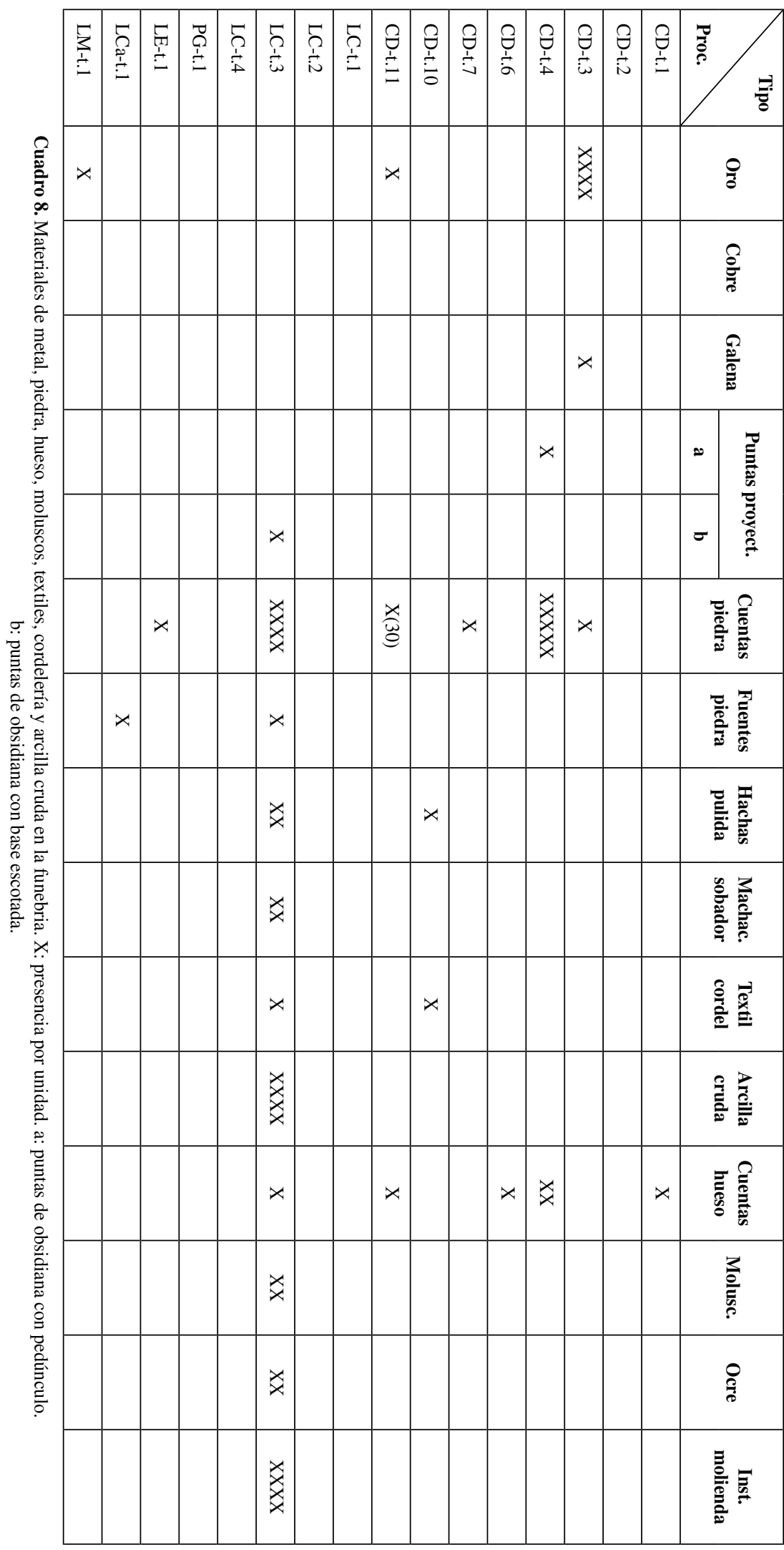


la arquitectura oblitere la prueba arqueológica. El segundo factor no resuelto proviene de la ausencia de un mecanismo paleozoológico eficiente que permita identificar, fehacientemente, entre los restos óseos del género Lama, los pertenecientes a Lama glama (llama) de los de Lama guanicoe (guanaco). Pero no obstante ello, no hay dudas en que algunas pruebas marcan a la ganadería como fuente primordial de los recursos económicos de estas aldeas. Estas pruebas son dos: una es la presencia de textilería y cordelería a partir de materias primas provenientes de la llama, y la segunda es que el control de la ganadería queda evidenciado por las muestras orgánicas de los basurales, deduciéndose una selectividad en la matanza de individuos muy jóvenes o muy viejos de llamas, dejándose los adultos como vientres y sementales. De la muestra total de restos orgánicos de camélidos, el $45 \%$ corresponde a individuos muy jóvenes y nonatos, y el 55\% restante a adultos de avanzada edad. Este registro permite comprobar la puesta en práctica de un principio básico de la ganadería, mediante la selectividad de los animales sacrificados para consumo y los preservados para la reproducción y crianza. Este principio de selectividad es elemental de la crianza, no sólo de la llama sino de cualquiera otra especie doméstica, y nunca puede ser atribuido como propio de una actividad rudimentaria como la caza, como pretende hacerlo Núñez Regueiro al tratar la economía, precisamente, del Formativo Inferior, cuando infiere que:

“...en los basureros de Campo Colorado, Prov. de Salta [investigaciones hechas por Tarragó], la inmensa mayoría de los restos óseos de animales corresponden a individuos muy jóvenes o viejos de guanaco, lo que indicaría la ausencia de pastoreo de llamas con fines alimenticios, y la gravitación de la caza para una cultura ya francamente agrícola..." (1974: 177).

Considero que existe un doble error en esta interpretación: primero en la identificación del guanaco, lo cual es empíricamente imposible por el momento, y segundo, aunque ello haya sido posible, es absurdo suponer que un grupo de caza, con la rudimentariedad de sus medios, haya tenido la posibilidad de seleccionar de tal forma sus presas, máxime teniendo en cuenta que el guanaco es más difícil de cazar que la llama. ${ }^{6}$

6 Además, si hubo selectividad por la edad de las presas, ¿por qué ésta sólo era aplicada con el guanaco y no también con la llama y vicuña?
En conclusión, hecho el planteamiento de la problemática, me inclino totalmente por la ganadería de la llama como actividad económica básica; relegando la caza a un papel secundario o, en todo caso, inversamente proporcional a la ganadería. Esto es, que a medida que aumentaban los aportes de la crianza de la llama, disminuirían los de la caza.

Los aportes agrícolas han debido ser incipientes en los inicios del Formativo (ocupaciones iniciales de LC.) aumentando paulatinamente en el transcurso del tiempo. Sobre los finales del Formativo Inferior (100 a 400 DC) supongo que los recursos agrícolas aportarían un 30 a 35\% del potencial económico. Además de los restos de maíz carbonizados hallados en CD.s.XVII y CD.s.XVIII, y de calabaza, el registro vinculado con las actividades agrícolas se compone de hachas planas con gargante (azadas), gran variedad y cantidad de instrumental para molienda de semillas ${ }^{7}$, ollas globulares halladas en los patios centrales, utilizadas como depósitos, y los hallazgos de infraestructura ligada a los cultivos, fragmentarios pero presentes, como los canchones de Cerro El Dique y Potrero Grande, alojados dentro de la franja fértil o fondo de quebrada, contiguos a las aldeas. El sistema de cultivo debió ser mixto, con profundas limitaciones técnicas, dependiente del temporal o, tal vez, con algunos intentos de riego manual.

El producto económico se completaría con las actividades de caza, las que, como dijimos, debieron ser relevantes durante el primer momento, para luego perder vigor ante el paulatino aumento de la ganadería y agricultura. No obstante, la caza nunca fue olvidada totalmente, dado que su registro perdura hasta el Período Inca. Los indicadores vinculados con la caza son los restos orgánicos de especies no domesticables, como el guanaco y vicuña, las aves (pato silvestre, flamenco), roedores varios (chinchilla, vizcacha de la sierra, cavia, etc.). La caza fue instrumentada con puntas de proyectil pedunculadas en un primer momento, luego con base escotada, confeccionadas en obsidiana y cuarcita; no es posible comprobar si estaban arrojadas con propulsor o con arco. También con piedras bolas

La vinculación del instrumental de molienda con actividades recolectoras es improbable, dado que estos ambientes (si vale la simulación de la ecología actual) de borde de Puna no son aptos para los vegetales de frutos y semillas comestibles (leguminosas como algarrobo, chañar, mistol, molle, tala, etc.). 
arrojadizas, ovoidales y esféricas, impulsadas con hondas de cordel y cuero. Los registros orgánicos obtenidos mediante la caza ocupan entre el 18 al $35 \%$ de las muestras de basurales (capas más profundas), posteriormente decrecen significativamente en las capas medias y superiores de las seriaciones, indicando que su importancia disminuyó a medida que aumentó el consumo del camélido domesticado y de los cultígenos.

De acuerdo con la distribución de estas seis aldeas, dentro de un ámbito de quebrada alta y estrecha del borde de Puna, desde Puerta Tastil hasta el altiplano, y desde la sierra del Chañi (por el este) a la del Acay (por el oeste) suponemos que el probable radio de influencia de ellas ha sido el ambiente ecológico de quebrada alta y fresca, entre 2500 a $4000 \mathrm{~m}$ de altitud. La superficie aproximada que ha estado bajo el radio de acción de las seis aldeas es de unos $1500 \mathrm{~km}^{2}$, lo cual permite calcular, apelando a información arqueológica (número de recintos para vivienda), que este ámbito pudo albergar a una población máxima relativa de aproximadamente 1000 a 1500 habitantes; es decir, entre $0.5 \mathrm{a} 1 \mathrm{hab} / \mathrm{km}$. Si es válido efectuar una simulación de las condiciones ambientales del Formativo, apelando a la proyección de las actuales, la quebrada del Toro ha debido encontrarse desprovista de recursos naturales que provocaran las actividades recolectoras de frutos y semillas silvestres. Se trataría, más bien, de un hábitat de estepas propuneñas, ideal para la ganadería, tal como ocurre en la actualidad (Raffino 1975: 32).

En períodos posteriores al Formativo Inferior, se comprueba el pasaje de una agricultura de altura, bien especializada y con riego artificial, que llega a equilibrar a los recursos ganaderos. Este fenómeno es propio de los desarrollos regionales. Pero si durante el Formativo las actividades económicas relevantes se basaron en el pastoreo de llamas en estepas, no deberá descartarse la hipótesis de migraciones alternadas (de población y de llamas) entre las aldeas. Es decir, una parte de la población que, no obstante la estabilidad de las aldeas, podía trasladarse, por un desprendimiento de una parte de los linajes familiares, de una aldea a otra, o a nuevas comarcas, dando origen a otra instalación, en la búsqueda y renovación -por una particular trashumancia- de las potencialidades de la tierra.

La ausencia de una agricultura tecnificada, con riego, rotación de cultivos, fertilización, etc., ha debido ser también un factor condicionante a esta circulación interna al hábitat de la quebrada; mecanismo que permitiría el descanso regenerativo de la tierra afectada a la agricultura, de las estepas destinadas al pastoreo y, aún de los cotos de caza, impidiéndose, consecuentemente, la sobrepoblación de las aldeas, tal como se observa en el registro arqueológico. Ya hemos expuesto en reiteradas oportunidades (Raffino 1972, 1975; Cigliano y Raffino 1973, 1974) cómo la ausencia de estos mecanismos autorreguladores pudieron ser la causa básica de la destrucción, como entidad sociopolítica, de los poblados urbanizados tardíos de Tastil, Morohuasi y Puerta Tastil. Durante el Formativo Inferior estos mecanismos pudieron representar la causa fundamental de la notoria estabilidad temporal de las aldeas, mantenida por espacio de 900 años.

De lo expuesto, así como vista la relevante similitud entre los patrimonios de las aldeas, lo cual implica un gran intercambio de bienes, es factible inferir que el modo de producción ha condicionado en las aldeas una cierta dinámica interna que se tradujo en desplazamientos de segmentos de población de un sitio a otro - una ida y regreso al lugar-, o hacia nuevas comarcas, favoreciendo una constante renovación ecológica; evitando el deterioro ambiental por la sobreexplotación, desplazándose dentro de hábitats análogos al cual estaban adaptados. Estos mecanismos, sin embargo, no deben contraponerse con la posibilidad de que dos, tres, o todas las aldeas fueran habitadas al mismo tiempo, ni tampoco pretende suponer que este modo de vida creó una especie de ecosistema cerrado, interno a la quebrada del Toro. Por el contrario, las vías de acceso cultural con otros ámbitos estuvieron bien abiertas para el hombre; como prueba de ello poseemos suficientes indicadores arqueológicos (ver más adelante).

Estos mecanismos de adaptación cultural a un ambiente ecológico específico puede ser la causa primordial que favoreció, aunque parezca contradictorio, la notoria estabilidad temporal de las aldeas formativas inferiores. Provistas de un ritmo de crecimiento económico lento, muy regulado por propias limitaciones internas, estabilidad que se prolongó por espacio de 900 años, para dar paso con el advenimiento de innovaciones tecnológicas e infraestructurales, especialmente la agricultura intensiva con riego artificial, y una mejor utilización del espacio dentro de las aldeas, a las poblaciones 
conglomeradas del Formativo Superior (400 a 1000 DC), de Cerro La Aguada y Tres Cruces. ${ }^{8}$

Cada aldea del Formativo Inferior, en su momento de ocupación, podría ser autosuficiente y de vida económica independiente, dueña de sus espacios vitales para la vivienda, las prácticas del pastoreo de llamas, la agricultura y sus cotos de caza. En ellas se producirían las tecnologías y materias primas con pequeños excedentes (hay hornos para cerámica y depósitos para comestibles), lo que les permitiría intentar la aventura del trueque, tanto interno como externo a sus radios de influencias. De este modo se explicaría la existencia de tecnologías, materias primas y copias de artesanías, oriundas de ámbitos aledaños, como Quebrada de Humahuaca, Puna, valle Calchaquí y selvas y bosques del oriente, que llegaron a formar parte de su patrimonio, como las alfarerías corrugadas, las hachas pulidas con garganta, las pipas de cerámica y piedra, los sopladores rectos, así como restos orgánicos de aves y cultígenos que, de acuerdo con la información actual, debieron ser introducidos a la quebrada del Toro desde los ámbitos orientales, sea de Humahuaca y del Chaco salteño, asimilados por las entidades locales, para trascender hacia el valle Calchaquí y comarcas meridionales, tal como parece insinuarlo la información.

\section{Sociopolítica}

Lo aquí expuesto pertenece a un nivel de inferencias muy complejo, plagado de riesgos inherentes con la naturaleza del registro arqueológico. Pero que, como antropólogos, y siendo una de las finalidades de la antropología arqueológica la reconstrucción de las formas de vida social del pasado, al menos en forma de proposiciones (hipótesis), no podemos dejar de intentar. Ya se ha adelantado en el capítulo precedente el supuesto

8 Cerro La Aguada ha sido preliminarmente tratado por Raffino (1972: 172). Una posterior lectura de $\mathrm{C}^{14}$ ha permitido fecharla en $680 \pm 50$ DC (CSIC.124), fecha que se corresponde ampliamente con la inferida mediante la cronología cerámica. Tres Cruces es otra aldea conglomerada de la quebrada; permanece inédita hasta ahora. Un reciente fechado (CSIC.125) ubica el origen de la instalación en el 310 DC pero su contexto, similar al de Cerro La Aguada, pertenece al Formativo Superior. Con relación a los sistemas agrícolas con regadío artificial, ya hemos sugerido la hipótesis que su implantación en el Noroeste Argentino se ha efectuado durante el Formativo Superior, a partir del siglo IV o V DC (Raffino 1975: 27), las pruebas arqueológicas así parecen evidenciarlo. de que cada aldea y su radio de influencia vecinal (campos agrícolas, estepas de pastoreo y cotos de caza) haya podido ser el espacio físico controlado por un grupo sociopolítico autónomo, basados en la hipótesis de que cada una de ellas poseía una economía autosuficiente.

El patrón de instalación y la funebria colectada especialmente en Cerro El Dique, Potrero Grande y Las Cuevas sugieren la existencia de una estructura social interna sobre la base de la familia extensa, compuesta por más de una pareja matrimonial. Cada una de ellas ocupando unidades habitacionales semisubterráneas, pequeñas, circulares y radiales a un patio central; este último lugar donde se realizaban actividades domésticas, artesanales y se enterraban los muertos. Cuanto mayor era el número de integrantes de la familia extensa, mayor sería el de habitaciones concéntricas al patio. En la aldea de Las Cuevas, la más antigua cronológicamente, podría suponerse una variante a este patrón; allí la posesión familiar se ejercería sobre los montículos, los que no eran abandonados aunque las viviendas se destruyesen. Si esto último ocurría, era edificada otra habitación encima de las ruinas, aumentando la altura de los túmulos y produciendo las superposiciones detectadas en las excavaciones.

Cada una de las familias extensas pudo estar compuesta por más de una pareja con sus hijos. Dentro de ellas podría haberse practicado una división del trabajo o funciones, de acuerdo a las edades, sexo y aptitudes de cada individuo dentro del marco de la producción. A partir de esta división del trabajo, interna a cada familia extensa, pudo generarse una diferenciación en "rangos" y funciones, lo cual se insinúa a través de la presencia de algunas tumbas, ubicadas debajo de los patios centrales, provistas de ajuares funerarios excepcionales, que denotan una jerarquización de algunos individuos, mediante el tratamiento selectivo y preferencial de sus cadáveres. Tal es el caso de la tumba CD-t.3 que pudo pertenecer a un individuo de rango jerárquico del grupo familiar CD.U.H.4. En otros casos se evidencia una especialización de los ajuares, que puede indicar el tipo de actividad que desempeñó el individuo en vida, como la tumba LC-t.3, hallada debajo de un recinto en Las Cuevas, que pudo pertenecer a un artesano ceramista de un grupo familiar del montículo norte del sitio. Esta tumba brindó todos los elementos necesarios para la manufactura de la alfarería, incluso piezas de arcilla cruda. 
Cada aldea pudo estar integrada por un conjunto de familias extensas. Aquí queda planteada la alternativa si, dentro del área de influencia controlada por la aldea, cada familia podría ejercer la posesión de sus rebaños de llamas, campos agrícolas y cotos de caza, de la misma forma que pudo ejercerla sobre el espacio físico destinado a las viviendas, patio central o funeraria; o bien, esta posesión podría ser de carácter comunal.

Dentro del marco de la familia extensa, las relaciones de parentesco permitirían que cada una de ellas diversificara las tareas propias de un modelo económico mixto (ganadería-agricultura-caza), practicándose una división del trabajo que elevaría el nivel de la productividad y absorbería, entre los integrantes, los riesgos económicos propios de un aparato productor poco tecnificado.

A partir de esta estructura social inferida, de familias extensas, con posible diferenciación de funciones y jerarquías, así como división del trabajo, podría explicarse, quizás, la dinámica o circulación interna y externa, o trashumancia entre las aldeas. Esto es por medio de desprendimientos esporádicos de parejas matrimoniales que, o bien dentro del perímetro de la aldea, darían lugar a la edificación de una unidad habitacional -habitación en torno a patio- o de producirse, por razones ecológicas, una acción migratoria o trashumante hacia otros sitios, permitirían los mecanismos de autorregulación demográfica que he tratado en el capítulo precedente.

\section{Cronología y bienes patrimoniales}

La posición estratigráfica de los tipos de la alfarería, así como una preliminar ubicación de ésta y demás tecnologías del Formativo, habían sido consideradas en anteriores contribuciones, a cargo de Cigliano (1970), Cigliano y colaboradores (1972), Raffino y Togo (1970). La coordinación de las seriaciones de los basurales de Cerro El Dique, Potrero Grande y Las Cuevas ha permitido obtener una secuencia cerámica regional más detallada y provista de mayor número de indicadores. Asimismo, ésta es ahora situada con mayor exactitud cronológica, gracias a la obtención de cuatro nuevas fechas radiocarbónicas: dos más en Las Cuevas, una en Cerro El Dique y una en Potrero Grande (Gráfico 1). ${ }^{9}$

9 Los fechados radiocarbónicos que responden a las siglas CSIC fueron procesados en el Instituto de Química Rocasolano, Laboratorio de Geocronología de Madrid. Los primeros
Los grupos de las alfarerías grises (Las Cuevas Gris Pulido y Cerro El Dique Gris Pulido Fino) y rojos (Las Cuevas Rojo Pulido Pintado y Cerro El Dique Rojo Alisado) pertenecen al momento más antiguo de la ocupación de la aldea Las Cuevas (niveles 5 y 6 de las estratigrafías artificiales). A esta época corresponde el fechado obtenido en la capa LC.s.IV.c.5, de 535 \pm 60 AC (GrN. 5852: 2485 \pm 60 AP). ${ }^{10}$ Técnicamente corresponden a piezas con escasa, y más frecuentemente, carentes de decoración. Las formas clásicas corresponden a pucos hemisféricos de borde reforzado (variedad C. 2 de Las Cuevas Gris Pulido), vasos cilíndricos de paredes verticales con un asa vertical y base plana (variedad D.1 de Las Cuevas Gris Pulido), así como ollas subglobulares de silueta restringida (variedades A.1 y A.2 de Las Cuevas Gris Pulido).

Dos técnicas, una de manufactura y la restante decorativa, podrían caracterizar, entre la cerámica, la modalidad del momento alfarero inicial del Formativo Inferior. Una de ellas sería la técnica de decoración mediante pintura postcocción, con colores rojo y amarillo, ejecutados a la manera de manchas, a veces indiferenciadas, otras quizás como "manos en positivo", autocolocadas sobre la superficie externa de las piezas. Esta técnica es observada en las ollas subglobulares y los vasos cilíndricos obtenidos en la funebria. La restante modalidad, no definitivamente comprobada en cuanto a la posible ubicación en el momento inicial, es el uso de la cestería como moldes para la confección de la cerámica, lo que ha dejado como testigos las improntas en negativo sobre la superficie exterior de las piezas, especialmente en las bases.

Prosiguiendo con el momento más antiguo de la seriación, desde el punto de vista cuantitativo, la alfarería monocroma gris prevalece notoriamente por sobre la roja (40 a $45 \%$ para la gris, $20 \%$ para la roja). Los tipos que acompañan son Las Cuevas Ordinario (15\%) y Cerro El Dique Gris y Rojo (15\%). El predominio del tipo Las Cuevas Gris Pulido es

fechados del sitio Las Cuevas, dados a conocer por Cigliano (1970) y Cigliano y colaboradores (1972), que responden a las siglas $\mathrm{GrN}$, lo fueron en el Laboratorio de Gröningen Universitet, Holanda.

10 A estos cuatro fechados deben adicionarse los registros nuevos de las aldeas conglomeradas de Cerro La Aguada y Tres Cruces, de significativa importancia, por cuanto han permitido medir con mayor precisión al Período Formativo Superior. 


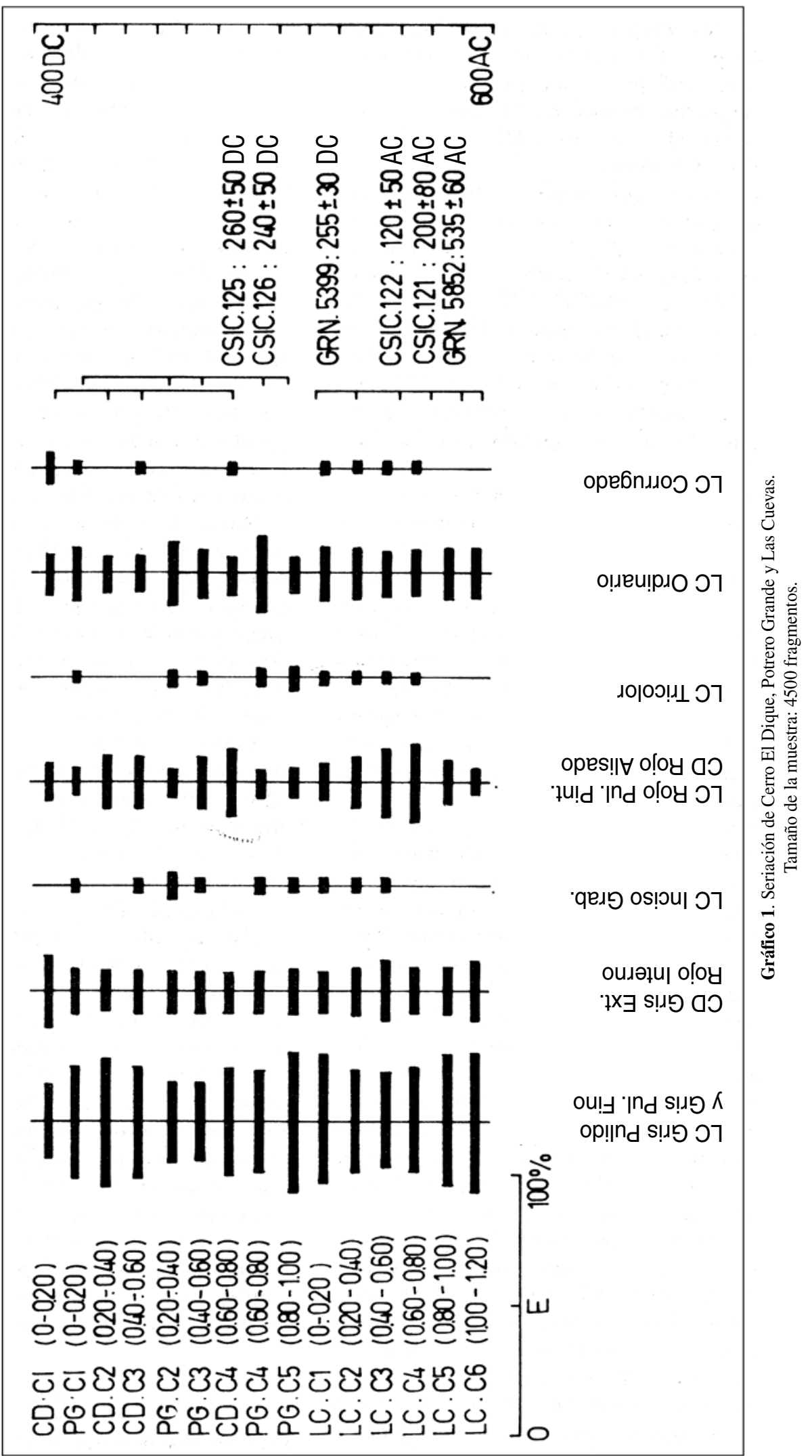


notorio, tanto en los materiales de funebria como de basurales. A lo largo de la secuencia seriada, las frecuencias de la cerámica gris, se mantienen en proporciones de 50 a $60 \%$ por unidad estratigráfica. Indudablemente la alfarería gris pulida ha sido usada tanto en las actividades domésticas como en las ceremoniales.

En síntesis, podría concluirse que uno de estos dos grupos cerámicos más antiguos de la seriación, por su posición estratigráfica, configura lo que puede ser conceptualizado como un horizonte monocromo gris, dado que su registro y asociación no son exclusivos de la quebrada del Toro, sino que posee gran dispersión en el ámbito de las llamadas subáreas valliserrana y Puna, también en San Pedro de Atacama y sur del altiplano boliviano. En Argentina, además de los seis sitios de la quebrada del Toro, ha sido identificado en San Lucas y Tacuil II (Cigliano y Raffino Ms), Campo Colorado (Tarrago y Díaz 1971: 51), todos éstos dentro del valle Calchaquí. También en Antofagasta de la Sierra y Tebenquiche; el segundo, estudiado por Krapovickas (1955) es el sitio tipo de la alfarería gris pulida. Aparece también en varios sitios enrolados dentro de la llamada fase Diablo, de González, en los valles meridionales de Catamarca y La Rioja.

Estratigráficamente por encima de estos niveles con grupos grises y rojos, dentro de las capas medias de Las Cuevas (c.3 y c.4) y más bajas de Cerro El Dique y Potrero Grande, en un momento datado en $200 \mathrm{AC}$ (CSIC.122: 2150 $\pm 80 \mathrm{AP}$ ), la secuencia seriada marca la aparición de un conjunto de tipos cerámicos de gran riqueza técnica y estilística. Ellos son el tipo Las Cuevas Tricolor, el Las Cuevas Corrugado y las alfarerías grises finas y bruñidas (Cerro El Dique Gris Pulido Fino y Las Cuevas Inciso Grabado) decoradas con incisiones y grabados, a veces rellenas con pigmentos rojo y amarillo y apéndices en motivos biomorfos y asas, aplicados al pastillaje. Ya en una contribución anterior (Cigliano et al. 1972: 233) habíamos sugerido una posible gran antigüedad -por cálculos estratigráficos- para estos grupos cerámicos, especialmente el Las Cuevas Tricolor, perteneciente a la Tradición Condorhuasi, con una cronología relativa estimada en 200 AC para la quebrada del Toro. Esta posición ha sido respaldada con la exactitud que aporta el $\mathrm{C}^{14}$.

Las frecuencias con que aparecen estos tipos son siempre inferiores al $10 \%$ por nivel. Se observa una leve tendencia a aumentar sus frecuencias a medida que se avanza hacia las capas superiores. Naturalmente estos porcentajes son más altos cuando se refieren a muestreos provenientes de ajuares funerarios. Especialmente aumentan los tipos Las Cuevas Gris Pulido y Las Cuevas Inciso Grabado (las pipas, los vasos biomorfos y las aplicaciones decoradas).

Otro indicador relevante de este segundo momento alfarero es la aparición de los vasos antropomorfos, anulares y zoomorfos (en tipos Las Cuevas Tricolor, Las Cuevas Gris Pulido y Cerro El Dique Gris Pulido Fino), así como las pipas angulares en color gris y castaño amarillento (color base del tricolor); provistas de decoración incisa (motivos geométricos) y adornos aplicados. Aparece también la alfarería Las Cuevas Corrugada, con formas de pucos grandes, de borde abierto, angular y labio reforzado; así como las urnas para infantes, de base cónica y asas verticales (variedades A, B y C de Las Cuevas Corrugado), decoradas con gruesas incisiones mediante la técnica dígito-unguicular, y otras veces con espátula. En general se observan piezas de excelente factura, $o$ bien a tres colores, o al pastillaje, o con grabados que pueden estar rellenos con pigmento rojo o amarillo. Esta última técnica, de postcocción, sobre ceramios grises y rojos. También hay figurinas antropomorfas de cuerpo completo, confeccionadas al pastillaje, sobre alfarería gris, con adornos corporales, sexo y extremidades inferiores. Pueden ser macizas y huecas (las primeras pueden ser más antiguas).

Cronológicamente cabe destacar que, además del fechado mencionado, se ha obtenido otro de $120 \pm 50$ AC (CSIC 122: 2070 AP) dentro del piso de un recinto circular con paredes de piedra y adobe, excavado en el montículo norte de Las Cuevas, el que, por asociación, corresponde a este momento alfarero.

Entre 100 AC y 400 DC, la alfarería decorada del Formativo Inferior llegaría a su punto más destacado. Este lapso de la secuencia seriada corresponde a los niveles medios de Potrero Grande y Cerro El Dique, y los superiores de Las Cuevas. Este es el momento donde se registran la mayoría de formas y variedades decorativas sistematizadas en la tipología. Dos nuevos fechados apoyan cronológicamente la información: 260 \pm 50 DC para Cerro El Dique (CSIC. 123: 1690 \pm 50 AP) de una muestra obtenida del piso de CD.U.H.4; y 240 50 DC (CSIC. 126: 1710 AP), obtenido de un lente de carbón vegetal en uno de los depósitos de basura de Potrero Grande (PG.s.IVC. III). ${ }^{11}$

\footnotetext{
11 A estas dos lecturas debe sumarse la fecha de $255 \pm 30$ (GrN. 5399) obtenida de las capas superiores de la serie estratigráfica de Las Cuevas. Dada a conocer por Cigliano (1970).
} 
En cuanto a los tipos Las Cuevas Ordinario y Cerro El Dique Gris y Rojo, se trata de ceramios carentes de rasgos relevantes, tanto en decoración como en formas. La frecuencia de aparición de estos tipos en basurales es muy regular a lo largo de la secuencia: entre 15 a $35 \%$ para cada tipo. Ambos están ausentes en la funebria. Técnicamente, sus manufacturas y huellas de uso, así como su ausencia en la funebria, permiten deducir un uso exclusivamente doméstico. Sus frecuencias, relativamente bajas para ceramios utilitarios, colectados en basurales, obedecen a que, como ya anticipáramos, también la cerámica Las Cuevas Gris Pulida se usó para actividades domésticas.

La posición cronológica de otros bienes patrimoniales del Formativo Inferior ha sido conocida ahora con mayor precisión. La utilización de la piedra y adobe como materia prima para la arquitectura, así como la mayoría de los rasgos arquitectónicos expuestos en el Cuadro 2, han sido practicados desde los inicios (600 AC). Asimismo, sobre la base de que Las Cuevas es la más antigua de las aldeas, podemos suponer que el patrón de instalación sobre montículos fue propio del comienzo, para ser luego reemplazado por las instalaciones como Cerro El Dique, más diseminadas, con núcleos habitacionales más grandes, con mayor cantidad de recintos en torno a los patios centrales.

La posición cronológica de algunas de las tecnologías muebles más destacables, como el uso de los metales en frío (oro, galena, cobre y plata); las hachas de piedra pulida con garganta; las pipas angulares y sopladores de cerámica y piedra; las alfarerías corrugadas, tricolor, así como los vasos antropomorfos, zoomorfos, anulares, las figurinas de arcilla; la decoración de líneas geométricas incisas grabadas rellenas con pigmento rojo y amarillo, la utilización de la técnica de la pintura postcocción y la escultura lítica ceremonial. Todos ellos poseen ahora una más precisa ubicación temporal. La fecha de 200 AC jalona el nivel estratigráfico que contiene ya estos bienes. No obstante, es posible que algunos de ellos, como las pipas en alfarería gris, la corrugada plástica y la ya mencionada técnica de pintura postcocción, puedan bajar más su antigüedad, siendo introducidas, en la quebrada del Toro, en el momento de la ocupación inicial del Formativo Inferior.

\section{Origen}

Las conexiones filogenéticas, entre sitios arqueológicos provistos de analogías formales, y ubicados dentro de etapas homotaxiales en el proceso, han sido no sólo el tema más apasionante de la arqueología contemporánea, sino el más difícil en cuanto a su comprobación. De estas dificultades no se halla exenta ninguna proposición que trate la génesis de las aldeas formativas inferiores de la quebrada del Toro. De modo que cualquiera sea la propuesta aquí presentada, ella no es más que una nueva aproximación a la problemática, y deberá ser considerada como tal.

Dos tesis antagónicas pueden ser formuladas dentro del tema filogenético de la cultura formativa del Noroeste Argentino, a saber:

1. Que su origen debe ser buscado fuera de los límites territoriales del Noroeste Argentino, sea alternativamente en la hoya del Titicaca, en los bosques orientales a los Andes, en las forestas tropicales de la región amazónica, o en la costa del Pacífico (Perú y norte de Chile). Llegando al Noeste Argentino por difusión, provista ya de un estado de desarrollo plenamente formativo (en los términos de Willey y Phillips 1958); es decir, superado ya el estado experimental que condujo a la domesticación de animales y cultígenos.

2. Que sea dentro del Noroeste Argentino donde se haya gestado el embrión del complejo agrícolaganadero-artesanal, que tipifica al Formativo, en un estadio cultural anterior, conocido como Arcaico Protoformativo, Agrícola Incipiente o, si se quiere, Protoneolítico.

La primera de estas dos hipótesis, en la que implícita o explícitamente se enrola la mayoría de los investigadores de nuestro medio, adquirió cuerpo durante los primeros momentos de la historia de la arqueología argentina, llegando a su punto más relevante durante la década de $1960 .{ }^{12}$ Su instrumentación, ya anticipada, se valió, entre otros aspectos, de la comparación, por analogías formales, de rasgos culturales, en base a la elección, arbitraria pero aceptada entre las reglas del juego, de aquellos que ofrecían similitudes, y permitían tender lazos de unión entre documentos arqueológicos homotaxiales formativos del Noroeste Argentino, con otros del área nuclear andina, o de las forestas tropicales orientales. En Ibarra Grasso (1958: 226) hallamos uno de estos ejemplos:

\footnotetext{
12 Sólo son considerados aquí los autores modernos, a partir de la diacronización de las culturas preeuropeas del Noroeste Argentino, y del momento en que es identificado el Formativo Meridional Subandino, o Agrícola Alfarero Temprano.
} 
“(...) la difusión que presenta esta cultura [se refiere a la cultura Megalítica, o de Chullpa-pampa, o de los Túmulos, es decir del Formativo Inferior del valle de Cochabamba] en Bolivia es, prácticamente, por toda la zona andina que conocemos, también es muy probable. que haya influenciado las regiones más cercanas de la floresta (...) igualmente su influencia parece haber abarcado mucho el Noroeste Argentino...”.

Esta línea de razonamiento llega, a mi juicio, a un punto destacado, con la contribución de González y Pérez (1966), que tuvo como antecedentes inmediatos a trabajos previos de González (1955, 1963a, 1963b). Ambos investigadores tendieron una conexión genética entre documentos arqueológicos de la llamada Area Andina Meridional, como Qaluyu, Pucara (Puno), Chiripa, Tiahuanaco I y II y Chullpa-pampa; Guatacondo, San Pedro I, Pichalo III, Molle I y II y Taltal (Chile). Dentro del Noroeste Argentino incluyeron a Tafí, Alamito, Otumpa, Condorhuasi, Candelaria, Ciénaga. Además habría que agregar otros, dados a conocer con posterioridad a esa publicación, u omitidos por los autores, como los 17 sitios de Wankarani (Ponce 1971), Caserones y Tarapacá 17 (Núñez 1972, 1974) y Turi (altiplano chileno). Dentro de nuestras fronteras a Tebenquiche (Krapovickas 1955), Agua Chica (Togo com. pers.), San Lucas, Amaicha y Tacuil II (Cigliano y Raffino Ms); Campo Colorado (Tarragó y Díaz 1972), así como las seis aldeas de la quebrada del Toro y varios sitios más de las llamadas subáreas arqueológicas Puna y valliserrana. González y Pérez concluyen su síntesis sobre el Formativo Meridional Subandino estableciendo:

\footnotetext{
“En general, el período impresiona, como integrado por grupos humanos que habiendo logrado dominar una serie de cultígenos de adaptación altiplánica (especies microtérmicas y papas) y animales domésticos (...) crecen y se expanden desde el altiplano en diversas direcciones, y particularmente hacia la Puna chilena y argentina, e inclusive hasta la costa, donde se establecen. Mientras tanto el área altiplánica va recibiendo nuevos aportes técnicos y nuevas tradiciones culturales, como los centros semiurbanos o urbanos (Qaluyu y quizás Pucara), la escultura en piedra y la alfarería más elaborada (...) en la periferia del Area [Andina Meridional], sobre todo en el Noroeste Argentino y este de Bolivia, se hizo sentir la influencia de la zona de los bosques occidentales y de las florestas tropicales; éstos trajeron nuevos recursos, y en los valles bajos
}

debieron incorporar nuevos cultígenos, sobre todo el maíz..." (1966: 17).

La obra de González y Pérez fue de suma importancia por su aporte de síntesis al proceso cultural aborigen. Otros aportes vinculados con la cuestión filogenética explicada en términos de difusión, del Formativo Meridional Subandino, fueron formulados por diversos investigadores, entre ellos González, que busca en: "el altiplano andino, especialmente en Bolivia", el origen de la alfarería inicial de Tafí (1963b: 52) y establece afinidades con Chullpapampa (como Ibarra Grasso), San Pedro I (oasis de Atacama) y Pichalo. Encuentra también similitudes de rasgos entre la alfarería Candelaria y grupos de las forestas tropicales "inclusive con alfarerías de Venezuela" (aunque el autor no lo dice, estimo que se refiere a las representaciones plásticas biomorfas de la fase La Cabrera) (1963b: 58).

Schaedel había visto similitudes entre Paracas, Chiripa, Condorhuasi y Molle (1957: 40). Núñez Regueiro (1971: 53) relaciona El Alamito con Chavín de Huaniar, Chiripa y Chullpa-pampa; ya en una contribución anterior, este autor, junto a González (1958: 158) habían tendido vínculos entre El Alamito, Chiripa y Tiahuanaco antiguo (estadio Aldeano de acuerdo a Ponce). Nosotros (Cigliano et al. 1972: 236) sugerimos conexiones genéticas entre Las Cuevas y Wankarani, a través del patrón habitacional. Núñez y colaboradores sugieren una: "causalidad altiplánica [Chullpa-pampa-Sora-SoraWankarani] para aceptar el Formativo Meridional" (1974: 2), tanto del Noroeste Argentino como del norte de Chile. Dougherty sostiene la existencia de un "aire de familia" en los inicios de San Francisco y Candelaria; como "producto de este proceso de difusión", "de rasgos que muestran un parentesco estilístico con las tierras bajas y el altiplano de Bolivia..." (1974: 145). Lumbreras sugiere también, aunque con cierta cautela, la conexión filogenética entre el Formativo Meridional y el Centroandino, basado en "una cantidad muy grande de convergencias dentro de un contexto económico-social tan similar" (1969: 143). Meggers infiere que los motivos geométricos incisos, elementos escalonados y otras figuras geométricas, tienen su "prototipo" en las cerámicas formativas del Area Andina (1972: 137). La nómina de investigadores, que interrumpo aquí, podría ser mucho más extensa. 
De acuerdo a esta corriente explicativa, la filogenia de los bienes culturales formativos inferiores de la quebrada del Toro, se entablaría de acuerdo con la siguiente discriminación (Figura 2):

1. De posible origen altiplánico-andino:

a) patrón arquitectónico circular,

b) habitación en torno a patio central,

c) uso de la piedra en la arquitectura y la escultura,

d) uso temprano de los metales,

e) tendencia a la policromía en la decoración alfarera,

f) uso de la pintura postcocción (Paracas Cavernas),

g) pipas o sopladores rectos,

h) entierros de adultos en cistas con techo de piedra,

i) economía básica de ganadería de la llama y agricultura de tubérculos y quinoa,

j) uso del tembetá o adorno labial (LE-t.1).

2. De posible origen en los bosques orientales y forestas tropicales:

a) alfarería corrugada o dígito-unguicular,

b) pipas angulares de cerámica,

c) hachas pulidas con garganta,

d) entierros de infantes en urnas,

e) bases cónicas y bordes angulares en la alfarería,

f) agricultura del maíz,

g) representaciones plásticas biomorfas en la alfarería.

Un párrafo aparte merece la controvertida alfarería polícroma (Las Cuevas Tricolor) para reiterar inferencias de una anterior contribución (Cigliano et al. 1972: 232) donde sugerimos una corriente difusoria que se deslizaría de norte a sur, cuyo origen no puede precisarse con exactitud, pero que, dentro del Noroeste Argentino, su dispersión tiene un ámbito específico: borde oriental y meridional de la Puna, quebradas altas del Toro, valle Calchaquí y subsidiarios, valle de Lerma, para llegar al corazón de la subárea valliserrana, el valle de Hualfín, dando lugar a la entidad conocida como Condorhuasi. Vale la pena ratificar que, para nosotros, la alfarería Las Cuevas Tricolor pertenece, no obstante presentar rasgos locales propios, en manufactura y decoración, a la tradición Condorhuasi, en consecuencia tiene una filogenia común.
En favor de la hipótesis de origen por difusión de rasgos altiplánicos andinos, pueden citarse los siguientes argumentos:

1. Que al occidente y dentro de la hoya del Titicaca-Poopó, el registro del Formativo Inferior es prolífico en sitios que pueden ser considerados como matrices de algunos rasgos culturales citados, como Wankarani, Qaluyu, Chiripa y, posiblemente, Tiahuanaco I y II, y Pucara.

2. Que la posición cronológica de algunos de estos sitios, en los alrededores de 600-1200 AC para Wankarani y Qaluyu (Rowe 1963: 6; Ponce 1970: 41), los habilita, en el parámetro temporal, como posibles generadores de influencias.

Los rasgos culturales compartidos, por similitud, entre Wankarani y la quebrada del Toro, serían los siguientes: ${ }^{13}$

1. Poblamiento en túmulos o montículos situados en los declives de cerros.

2. Superposiciones de recintos dentro de los montículos.

3. Arquitectura en piedra y adobe; las primeras clavadas verticalmente en el piso, como cimientos. Con techo perecible (de torta de barro $\mathrm{y}$ vegetales).

4. Patrón arquitectónico circular, con viviendas ubicadas colindantes unas con otras.

5. Túmulos rodeados con una pequeña muralla.

6. Patrón de poblamiento rural-aldeano. Cada aldea con su comarca de influencia, para actividades agrícolas-ganaderas y de caza.

7. Entierros de adultos en pozos cilíndricos con tapas de piedra. Ubicados en el sitio de vivienda, por debajo del piso de los recintos.

8. Figurinas de arcilla modeladas con motivos antro y zoomorfos.

13 No he incluido a Qaluyu dentro de este juego comparativo por analogías, por carecer desafortunadamente -salvo las menciones de Rowe (1963)- de información precisa de su contexto. 
9. Azadas líticas.

10. Uso temprano de los metales.

\section{Escultura lítica.}

\section{Economía andina altiplánica.}

13. Similitudes raciales entre los restos humanos (comprobación a cargo del Dr. Marcellino). Aunque debe consignarse que los restos óseos de la región del Titicaca-Poopó provienen de colecciones generales y no específicamente de Wankarani.

Los argumentos que oscurecen la conexión filogenética del Formativo Inferior de la quebrada del Toro hacia el altiplano son dos:

1. Falta de registro arqueológico sistemático, por ausencia de investigaciones, en el espacio físico que separa ambas regiones. Lo cual permitiría tender un encadenamiento de sitios sincrónicos análogos, detectando, de este modo, la ruta de la difusión.

2. Ausencia de investigaciones sistemáticas e intensivas en los sitios inferidos como posibles generadores, ubicados en la hoya TiticacaPoopó.

Con respecto a los elementos culturales con probable filiación en los bosques orientales y forestas tropicales, los argumentos utilizados se valen de las similitudes existentes entre la quebrada del Toro y los sitios ubicados al oriente, dentro de la región arqueológica de San Francisco (Cigliano et al. 1972, 1974; Dougherty 1972, 1974). Entre ellos, las alfarerías con aditamentos plásticos biomorfos y de técnica corrugada, las pipas angulares de cerámica; la cerámica gris con decoración de figuras geométricas incisas rellenas con pigmento rojo o amarillo; las hachas pulidas en piedra y provistas de garganta; las inhumaciones de párvulos en urnas. $\mathrm{Si}$ bien no existen mayores dificultades en atribuirles una posible vía de entrada a la quebrada del Toro desde San Francisco; inclusive se posee una lectura radiocarbónica que prueba sincronismo entre algunos de los rasgos compartidos, por medio de una muestra del sitio Saladillo Redondo dada a conocer por Dougherty $(1972,1974: 85)$ de 620 AC, la dificultad no radica en la conexión entre la quebrada y San Francisco, la cual está por demás probada, sino en la ausencia total de registro al norte y oriente de la región sanfranciscana. En otras palabras, falta la imprescindible información que permita corroborar la hipótesis de difusión, de norte a sur, con un origen, virtual en forestas tropicales o bosques orientales a los Andes, y una región receptora, el Noroeste Argentino, vía región de San Francisco.

Estos son, en una síntesis que trató de ser actualizada, los argumentos en favor y en contra de la tesis difusionista, como mecanismo explicativo al origen del Formativo de la quebrada del Toro, problemática ésta que puede ser extendible a todo el ámbito del Noroeste Argentino.

La segunda hipótesis explicativa del origen del Formativo en el Noroeste Argentino, en este caso como producto de un proceso interno e independiente, ha tenido muchos menos defensores. Su factibilidad, obviamente, dependerá de la información que se pueda obtener en el estudio del Arcaico o Protoformativo; especialmente los referidos al proceso que condujo a la domesticación de cultígenos y animales, así como la invención de artesanías, principalmente la alfarería, que son registradas con pleno desarrollo durante el Formativo. Frente a esta problemática creemos conveniente diferenciar dos cuestiones:

1. La primera se refiere al proceso de domesticación de algunos cultígenos y animales (llama) así como la incorporación de artesanías como la cestería y la textilería, la cual está evidenciada en el Arcaico del Noroeste Argentino y es el antecedente cultural directo de la etapa productora ganadera agrícola del Formativo.

2. La segunda cuestión concierne al problema particular de la alfarería, cuyos indicios se hallan ausentes en el Arcaico y posteriormente con desarrollo pleno durante el Formativo.

La primera de estas dos cosas comenzó a insinuarse con los trabajos de Lagiglia (1962) en Rincón del Atuel -Atuel III- y de Gambier y Sachero (1970) en la Cueva de Los Morrillos -Morrillos II-, tomando un cuerpo más substancioso con las recientes investigaciones de Fernández Distel y colaboradores (1974: 117), en los abrigos de Huachichocana e Inca Cueva. Los indicios de cultígenos como maíz, papa oca, maní, poroto, ají, achira y calabaza se encuentran estratigráficamente asociados con restos de camélidos, con semillas de algarrobo y con tecnología como la cestería, textilería e industrias de puntas líticas 


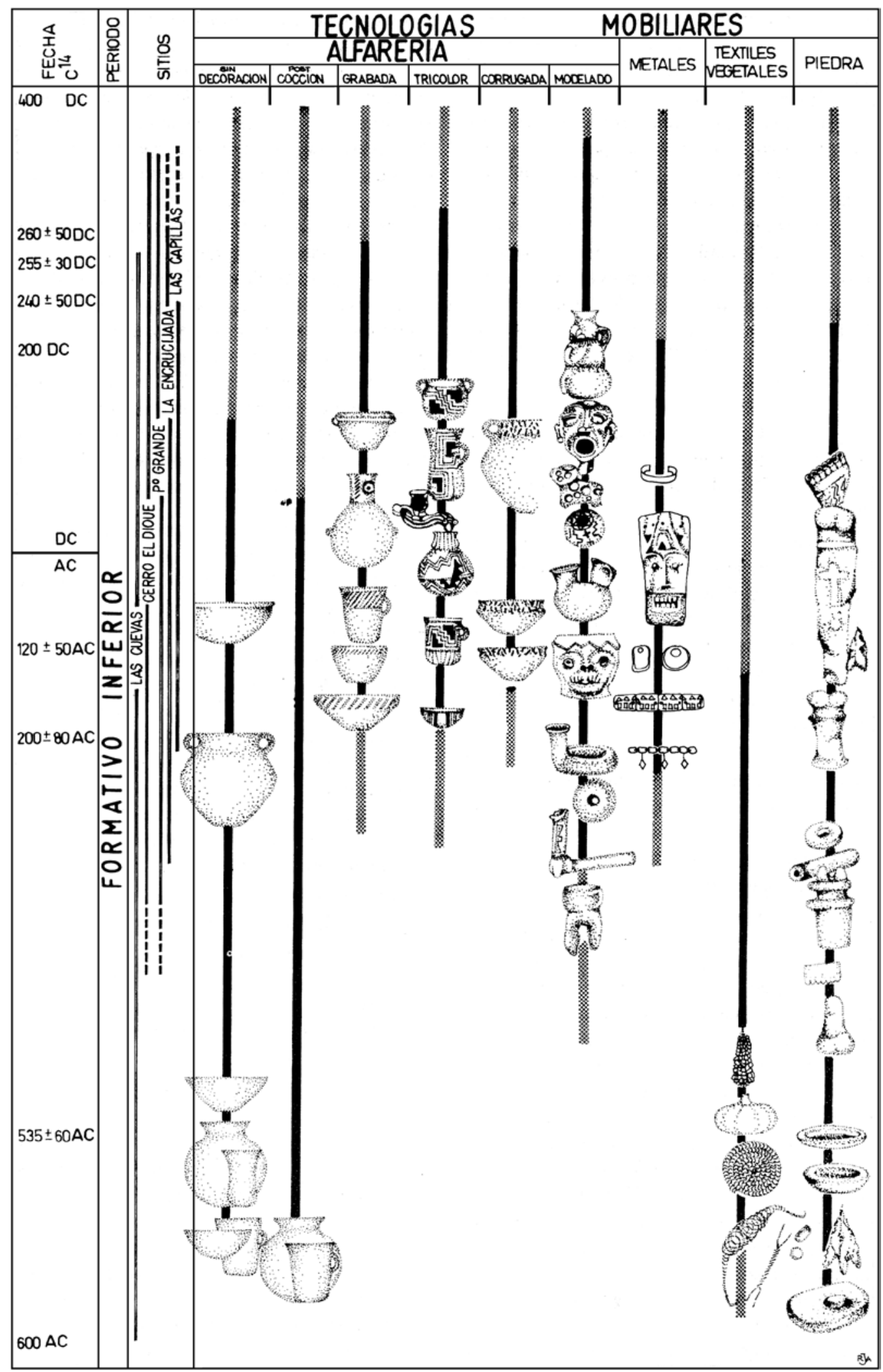

Figura 2. Tecnologías mobiliares del Formativo Inferior en la quebrada del Toro. 
triangulares en el nivel III de Huachichocana III, en un estadio que las autoras, apelando a los esquemas de Menghin, denominan Protoneolítico: "es decir, una base cazadora recolectora que, en su fase final, inicia la experimentación de una técnica neolítica [cultivo]" (1974: 122). En este contexto está ausente la cerámica. Llama la atención la gran antigüedad de este nivel III, tres registros radiocarbónicos ubicarían a los inicios del Protoformativo o Arcaico en los alrededores del 7000 AC. Pero si esta gran antigüedad puede, tal vez, ser puesta en tela de juicio, lo que no ofrece dudas es la filiación cultural Arcaica del nivel III de Huachichocana, la cual es extensible a otros sitios, como Huachichocana V e Inca Cueva c.7 (Aguerre et al. 1975: 211), y su tipificación como etapa experimental de algunos cultígenos.

La importancia de estos hallazgos es incuestionable, porque sugieren la prueba arqueológica de que el Noroeste Argentino pudo ser centro de domesticación de cultígenos. Especialmente recordando que algunos de los restos etnobotánicos exhumados en Huachichocana, se han dado en el Noroeste Argentino en forma silvestre, como el poroto $(P h$. aborigeneus) (Burkart y Brucher 1953), el zapallo criollo (C. andreana) (Parodi 1935: 144), el maní (A. monticola) (Krapovickas y Rigoni 1957) y la calabaza (C. moschata) (Parodi 1966: 35). Con excepción del zapallo criollo, los tres cultígenos restantes aparecieron en los niveles protoformativos o arcaicos de Humahuaca.

Conjuntamente con las evidencias de utilización de cultígenos, los niveles arcaicos de Huachichocana marcan la aparición de tecnologías que cumplen un papel francamente revolucionario, como la textilería, la cestería, efectuadas sobre materias primas de procedencia vegetal, humana (pelo) y animal (lama de camélido) (Fernández Distel et al. 1974: 118).

Hasta aquí las evidencias arqueológicas que sugieren la existencia de un posible centro de domesticación de cultígenos como poroto, maní y calabaza; con la factibilidad que a éstos, pueda adicionarse la llama $\mathrm{y}$, con mejores evidencias, las artesanías textiles y cestería, dentro del Noroeste Argentino, en una etapa francamente arcaica o protoneolítica. En cuanto a la presencia de maíz y papa oca dentro de un nivel tan antiguo, indudablemente atenta con los esquemas tradicionales sostenidos para las regiones marginales del Area Andina, entre las que se cuenta el Noroeste Argentino. Porque, no obstante cierta incertidumbre en la localización de los centros de domesticación de maíz y papa en América, no se mencionaba dentro de los probables, al Noroeste Argentino. No obstante el registro de maíz y papa de Humahuaca es aún fragmentario como para aventurar inferencias de corte filogenético. La última palabra a esta cuestión emanará de futuros trabajos de campo.

La segunda cuestión planteada es el registro de alfarería. Su ausencia en el Arcaico de Humahuaca obliga a suponer que la hipótesis de un mecanismo inventivo independiente, para el Noroeste Argentino, iniciado en el Arcaico y cristalizado en el Formativo, no tiene por el momento, posibilidades de comprobación. Especialmente teniendo presente el alto grado de desarrollo con que aparece la alfarería del Formativo Inferior de la quebrada del Toro, y de la extraordinaria dinámica evidenciada a través de una enorme dispersión espacial de estilos cerámicos tempranos -u horizontes-estilos- por el Area Meridional Andina. De modo que se hace más consistente la hipótesis de difusión, hacia el Noroeste Argentino, tal como se ha planteado en los términos aquí expuestos.

Como exégesis de todo lo considerado en el transcurso de este trabajo, analizados los argumentos pertinentes a ambas hipótesis filogenéticas del Formativo de la quebrada del Toro, se desprenden las siguientes propuestas:

1. Las aldeas de la quebrada del Toro deben ser ubicadas, en relación al parámetro tiempo, entre 600 AC y 400 DC. Tipificadas culturalmente en la secuencia preeuropea, dentro del llamado Período Formativo Meridional Subandino, Neolítico Regional Subandino, o Agrícola Alfarero Temprano.

2. En un marco espacial de ecología andina, el modelo económico se sostuvo en la crianza de la llama y su control con énfasis en la ganadería. En una agricultura poco tecnificada, con el complemento de la caza. Esta última actividad con vigor decreciente, a medida que aumentaban los aportes de la ganadería y de la agricultura.

3. El patrón de instalación de las aldeas sugiere fuertes vínculos, de índole genética, con sitios análogos del Formativo Inferior altiplánico, en especial al occidente y dentro de la hoya de los lagos Titicaca-Poopó. 
4. Este modelo económico ganadero-agrícola, con el complemento de la caza, tuvo antecedentes, dentro del proceso productivo, iniciados durante el Período Arcaico, Protoformativo o Protoneolítico del Area Meridional Andina. Su causalidad se explica, alternativamente, por la domesticación de algunos cultígenos de posible origen local, como la calabaza, el maní y los porotos; a los que se adicionan otros de origen más incierto, como el maíz, tubérculos, achira y la domesticación de la llama.

5. La incorporación de tecnologías artesanales y de producción en el contexto del Formativo Inferior, como el uso temprano de los metales, la alfarería, textilería, cestería y escultura-arquitectura en piedra, han sido el resultado alternativo de dos mecanismos posibles: la difusión, que ha podido actuar en mayor grado sobre la alfarería, metales y arquitectura-escultura lítica, y la posibilidad de un desarrollo local independiente de la cestería y textilería, gestado en el Arcaico de quebrada de Humahuaca.

6. Sobre esta base o sustrato cultural, con mayoría de rasgos altiplánicos introducidos por difusión, actuarían posteriores tracciones que incorporarían nuevas tecnologías, más depuradas en lo artesanal. Algunas de ellas de probable filogenia en bosques y forestas orientales a los Andes, cuyo acceso más posible han debido ser los bosques de la región de San Francisco, siguiendo hacia el sur la ruta trazada por los rasgos culturales altiplánico-andinos, como el patrón de instalación, y llegando a ocupar la mayor parte del ámbito conocido como Puna meridional y valliserrano del Noroeste Argentino.

La Plata, abril de 1976.

\section{REFERENCIAS CITADAS}

AGUERRE, A.M., A. FERNANDEZ DISTEL y C. ASCHERO, 1973. Hallazgo de un sitio acerámico en la quebrada de Inca Cueva. Relaciones de la Sociedad Argentina de Antropología VII: 197.

1975. Comentario sobre nuevas fechas en la cronología arqueológica precerámica de la provincia de Jujuy. Relaciones de la Sociedad Argentina de Antropología IX: 211.

BENNETT, W. y colaboradores, 1948. Northwest argentine archaeology. Yale University, Publications in Anthropology 38.

1936. Excavations in Bolivia. Anthropological Papers of American Museum of Natural History XXXV, IV, Nueva York.

BERBERIAN, E., 1972. Adornos transfictivos labiales en una tumba indígena de la provincia de Córdoba. Universidad Nacional de Córdoba, Córdoba.

BURKART, A. y H. BRUCHER, 1952. Phaseolus aborigeneus Burkart, die mutmassliche andine stammform der Kulturbohne, Der Zuchter XXIII: 65.

CIGLIANO, E. M., 1968. Sobre algunos vegetales hallados en el yacimiento arqueológico de Santa Rosa de Tastil. Revista del Museo La Plata, Antropología N.S., p. 15.

1970. Problemas referentes al sitio arqueológico de Las Cuevas, depto. Rosario de Lerma, Salta. Relaciones de la Sociedad Argentina de Antropología V (1).

CIGLIANO, E. M. y colaboradores, 1973. Tastil, una ciudad preincaica argentina, Ediciones Cabargón, Buenos Aires.
CIGLIANO, E. M. y H. CALANDRA, 1971. En torno a dos sitios precerámicos en el departamento de Rosario de Lerma, prov. Salta. Relaciones de la Sociedad Argentina de Antropología V (2): 153.

CIGLIANO, E. M. y R. RAFFINO, 1973. Tastil, un modelo cultural de adaptación, funcionamiento y desarrollo de una sociedad urbana prehistórica. Relaciones de la Sociedad Argentina de Antropología VII: 159.

1974. Tastil, un modelo de ecología urbana del Noroeste Argentino. Actas y Memoria de XLV Congreso Internacional de Americanistas. México D. F.

CIGLIANO, E. M., R. RAFFINO y H. CALANDRA, 1972. Nuevos aportes para el conocimiento de las entidades alfareras más tempranas del Noroeste Argentino. Relaciones de la Sociedad Argentina de Antropología VI: 225.

DOUGHERTY, B., 1972. Las pipas de fumar arqueológicas de la provincia de Jujuy. Relaciones de la Sociedad Argentina de Antropología VI: 83.

1974. Informe preliminar sobre un nuevo yacimiento arqueológico en Palpalá, prov. Jujuy. Relaciones de la Sociedad Argentina de Antropología VIII: 135.

FERNANDEZ DISTEL, A., 1974. Excavaciones arqueológicas en la cueva de Huachichocana, depto. Tumbaya, prov. Jujuy. Relaciones de la Sociedad Argentina de Antropología. VIII: 101.

GAMBIER, M. y P. SACHERO, 1970. Secuencias culturales y cronología para el suroeste de la provincia de San Juan. Hunuc Huar. Publicación del Museo Arqueológico de la Universidad D.F. Sarmiento I (1). 
GONZALEZ, A. R., 1955. Contextos y secuencias culturales en el área central del Noroeste Argentino. Anales del XXXI Congreso Internacional de Americanistas, p. 699. São Paulo.

1963a. Cultural development in Northwestern Argentina. Smithsonian Mis. Collect., 146 (1): 102.

1963b. Las tradiciones alfareras del Período Temprano del Noroeste Argentino y sus relaciones con las áreas aledañas. Anales de la Universidad del Norte 2: 49.

GONZALEZ, A. R. y V. NUÑEZ REGUEIRO, 1958. Apuntes preliminares sobre la arqueología de Campo del Pucara y alrededores (depto. Andalgalá, prov. Catamarca). Anales de Arqueología y Etnología, Facultad de Filosofía y Letras, Universidad Nacional de Cuyo XIV-XV: 115.

GONZALEZ, A.R. y J.A. PEREZ, 1966. El Area Andina Meridional. Actas y Memorias del XXXVI Congreso Internacional de Americanistas I: p. 241. Sevilla.

IBARRA GRASSO, D. E., 1958. Los primeros agricultores de Bolivia, Anales de Arqueología y Etnología, Facultad de Filosofía y Letras, Universidad Nacional de Cuyo XIVXV: 205.

KRAPOVICKAS, A. y V. RIGONI, 1957. Nuevas especies de Arachis vinculadas al problema del origen del maní. Darwiniana 11 (3).

KRAPOVICKAS, P., 1955. El yacimiento de Tebenquiche, Puna de Atacama. Publicaciones del Instituto de Arqueología, Facultad de Filosofía y Letras, Universidad de Buenos Aires III.

LAGIGLIA, H. y J. SEMPER, 1962. Excavaciones arqueológicas en el Rincón del Atuel (Gruta del Indio), depto. San Rafael, Mendoza. Revista Científica de Investigación, Museo de Historia Natural de San Rafael I (4).

LUMBRERAS, L. G., 1969. Acerca del desarrollo cultural de los Andes. Pontificia Universidad Católica del Perú. Mesa Redonda Ciencias Prehistóricas y Antropología II.

NUÑEZ, L., 1972. Cambios de asentamientos humanos en la quebrada de Tarapacá, norte de Chile (esquema interdisciplinario). Documentos de Trabajo 2.

NUÑEZ, L., V. ZLATAR y P. NUÑEZ, 1974 Ms. Relaciones prehistóricas entre el Noroeste Argentino y el norte chileno (Período Cerámico). Ponencia presentada en el $3^{\text {er }}$ Congreso Nacional de Arqueología, Salta.

NUÑEZ REGUEIRO, V., 1971. La cultura Alamito de la subárea valliserrana del Noroeste Argentino. Journal de la Societé des Americanistes LX: 7.

1974. Conceptos instrumentales y marco teórico en relación al análisis del desarrollo cultural del Noroeste Argentino.
Revista del Instituto de Antropología, Universidad Nacional de Córdoba V: 169.

PARODI, L. R., 1935. Relaciones de la agricultura prehispánica con la agricultura argentina actual. Anales de la Academia Nacional Agr. y Veterinaria I: 115.

1966. La agricultura aborigen argentina. Cuadernos de América, Universidad de Buenos Aires, Buenos Aires.

PONCE, C., 1970. Las culturas Wankarani y Chiripa y su relación con Tiwanaku. Academia Nacional de Ciencias de Bolivia, Publicación 25, La Paz.

RAFFINO, R., 1968. Contribución al estudio de los petroglifos de la quebrada de Tastil, depto. Rosario de Lerma, prov. Salta. Revista del Museo de La Plata, Antropología N.S. VII: 1.

1972. Las sociedades agrícolas del Período Tardío en la quebrada del Toro y aledaños, Prov. Salta. Revista del Museo de La Plata, Antropología N.S. VII: 157.

1973. Agricultura hidráulica y simbiosis económica demográfica en la quebrada del Toro. Revista del Museo de La Plata, Antropología N.S. VII: 297.

1975. Potencial ecológico y modelos económicos en el Noroeste Argentino. Revista del Museo de La Plata, Antropología N.S. IX: 21

RAFFINO, R. y J. TOGO, 1970. El yacimiento arqueológico de Cerro El Dique (nota preliminar), depto. Rosario de Lerma, Salta. Revista Itá Aripí, Depto. de Antropología y Folklore Concordia 1.

ROWE, J. H., 1963. Urban settlements in ancient Perú. Ñawpa Pacha I: 1.

SERRANO, A., 1967. Historia cultural del Tucumán prehispánico. Una introducción a la arqueología del Noroeste Argentino. Ampurias XXIX.

SCHAEDEL. R., 1957. Informe general sobre la expedición a la zona comprendida entre Arica y La Serena. Arqueología Chilena, p. 7.

TARRAGO, M. y P. DIAZ, 1972. Sitios arqueológicos del valle Colchaquí. Estudios de Arqueología I: 49.

UHLE, M., 1912. Las relaciones prehistóricas entre Perú y Argentina. Actas del XVII Congreso Internacional de Americanistas, p. 509. Buenos Aires.

VIVANTE, A. y N. PALMA, 1966. Habitaciones pozo y semipozo con paredes de guano en la Puna argentina. Revista del Museo de La Plata N. S. Antropología VI: 17.

WILLEY, G. y P. PHILLIPS, 1958. Method and theory in American archaeology. Phoenix Books, The University of Chicago Press, Chicago y Londres. 


\section{APENDICE \\ PALEOETNOZOOLOGIA DEL AREA DE LA QUEBRADA DEL TORO}

EdUARDo TONNI Y José LAZA ${ }^{1}$

En repetidas oportunidades arqueólogos de la Facultad de Ciencias Naturales y Museo de La Plata, abocados al estudio de sitios de asentamientos en el Noroeste Argentino, coleccionaron restos de vertebrados provenientes de ellos. Casi sin excepciones la determinación sistemática de esos materiales fue realizada por investigadores de la División Paleontología Vertebrados de esa Facultad, quienes no obstante los trabajos propios de su especialidad vieron con interés tales determinaciones, dadas las implicancias paleobiogeográficas y ambientales que de ellos podían derivar.

Llamó la atención el hecho de que aquellos materiales procedentes de sitios del llamado Período Formativo en el Noroeste Argentino incluían un alto porcentaje de restos atribuibles a Lama sp., y lo que resultó más llamativo aún, es que los restos de estos camélidos se discriminaban casi por igual entre individuos jóvenes y adultos.

Nuevos materiales coleccionados por personal de la División Antropología de la citada Facultad, procedentes de diversos sitios de asentamiento del área de la quebrada del Toro, provincia de Salta, reforzaron los hechos observados.

Estas nuevas evidencias, unidas al interés de los investigadores que ya se habían ocupado de aspectos arqueológicos del área (Cigliano 1970; Raffino y Togo 1970; Raffino 1972; Cigliano et al. 1972), motivaron la presente nota.

\section{Generalidades}

La quebrada del Toro, ubicada al nor-noroeste de la ciudad de Salta, en el ámbito geográfico de los Andes Orientales, se desarrolla prácticamente en dirección norte-sur, constituyendo la colectora principal de una

1 División Paleontología Vertebrados, Facultad de Ciencias Naturales y Museo, Paseo del Bosque, 1900-La Plata, ARGENTINA serie de quebradas laterales. El río Toro, de pendiente atlántica, es la vía fluvial más importante de la región, caracterizada en su conjunto por un paisaje en el estado juvenil de su ciclo geomórfico, con un diseño de avenamiento dendrítico y marcadas diferencias de altura entre pisos de valle y divisorias.

Los tres sitios de asentamiento de donde procede el material estudiado son Cerro El Dique, Potrero Grande y Las Cuevas. Se encuentran situados en alturas que varían entre los 3100 y 3400 m.snm. Los dos primeros están ubicados en la cabecera norte de la quebrada del Toro, a ambos lados del río Punta Ciénaga. Las Cuevas está situada sobre el margen derecho del río Las Cuevas, que corre por la quebrada homónima, tributaria de la del Toro.

Algunos valores de los elementos climáticos para el área se deducen de los datos provistos por la estación San Antonio de Los Cobres (Knoche y Borzacov 1947). La temperatura media anual oscila entre 5.1 y $10^{\circ} \mathrm{C}$; las máximas absolutas son del orden de los 25.1 a $30^{\circ} \mathrm{C}$; las mínimas absolutas son inferiores a $\operatorname{los}-10^{\circ} \mathrm{C}$. La precipitación media anual varía entre 110 y $200 \mathrm{~mm}$.

Zoogeográficamente el área está incluida en el Dominio Andino de la Subregión Andino Patagónica (Ringuelet 1961), caracterizada por una fauna orófila con elementos tales como Vicugna vicugna, Chinchilla sp., Hippocamelus antisensis, Octodontomys gliroides, entre los mamíferos, y Pterocnemia pennata garleppi, Chloëphaga melanoptera, Phenicoparrus jamesi, entre las aves.

La vegetación de las quebradas y laderas secas del área es de típica estepa arbustiva, con algunos elementos altamente xerófilos, que en conjunto caracterizan a la provincia prepuneña del Dominio Chaqueño (Cabrera 1971). Son características ciertas especies arbustivas áfilas como Cassia crassiramea y Aphyllocladus spartioides; los bosques de Prosopis ferox son conspicuos en el fondo de las quebradas secas. Las gramíneas son relativamente escasas, mientras que las cactáceas dan una fisonomía particular al 
paisaje, tal el caso de los cardonales de Trichocereus pasacana, las diversas especies de Opuntia, etc. En las laderas de pendientes muy pronunciadas son característicos los cojines de bromeliáceas.

\section{Métodos}

El material fue determinado a diferentes niveles, dependiendo ello de su estado de conservación y del valor sistemático de las distintas piezas anatómicas.

En los cálculos porcentuales se consideraron únicamente los taxa reconocidos a nivel genérico y/o específico, excepto cuatro casos en que se incluyeron en el porcentaje especímenes determinados sólo a nivel familiar, ya que no estaban representados -en la muestra examinada- por especímenes determinables a nivel sistemático más fino.

El número mínimo de individuos se calculó en base al recuento de piezas anatómicas perfectamente diferenciables y homogéneas para cada muestra, esto es: cráneos o ramas mandibulares derechas o izquierdas, o elementos del esqueleto apendicular derechos o izquierdos (estilopodio, zeugopodio o metapodio del autopodio).

La edad relativa de los individuos (jóvenes o adultos) se estimó por la presencia de molariformes deciduos o definitivos y/o por el grado de osificación de los huesos largos en los mamíferos. Tales criterios no pueden aplicarse a las aves, por lo cual para los escasos restos presentes no se efectuó la estimación de edad relativa.

\section{Sistemática}

Se dará aquí un listado sistemático de los distintos taxa reconocidos en cada localidad y el número mínimo de individuos para cada taxón.

\section{Las Cuevas}

Clase mammalia, Orden artiodactyla, Familia CAMELIDAE, Género LAMA (Frisch 1775), Lama sp.: 30 individuos.

Género vicugna (Gray 1872), V. vicugna (Molina 1782; Allen 1942): 4 individuos.
Familia CERVIDAE, Cervidae indet.: 2 individuos. Orden rodentia, Familia octodontidae, Género CTENOMYs (De Blainville 1826), Ctenomys sp.: 1 individuo.

\section{Potrero Grande}

Clase aves, Orden ANSERIformes, Familia ANATIDAE, Anatidae indet.

Clase mammalia, Orden artiodactyla, Familia CAMELIDAE, Género lama (Frisch 1775), Lama sp.: 19 individuos.

Orden Rodentia, Familia CHINCHILLIDAE, Género LAGIDIUM (Meyen 1833), Lagidium sp.: 1 individuo.

Familia octodontidae, Género octodontomys (Palmer 1903), Octodontomys gliroides (Gervais y D’Orbigny 1844; Thomas 1913): 1 individuo.

Género CTEnomys (De Blainville 1826), Ctenomys sp.: 1 individuo.

Familia CaviIdae, Subfamilia caviInae, Caviinae: 1 individuo.

\section{Cerro El Dique}

Clase mammalia, Orden artiodactyla, Familia CAMELIDAE, Género LAMA (Frisch 1775), Lama sp.: 25 individuos.

Género VICUgNa (Gray 1872), V. vicugna (Molina 1782; Allen 1942): 1 individuo.

Orden Rodentia, Familia CHINCHILlidae, Género CHINCHilla (Bennet 1820), Chinchilla sp.: 8 individuos.

Género LAGIDIUM (Meyen 1833), Lagidium sp.: 1 individuo.

Familia octodontidae, Género ctenomys (De Blainville 1826), Ctenomys sp.: 1 individuo.

Familia CAVIIDAE, Género PEDIOLAGUS (Marelli 1927), P. salinicola (Burmeister 1876): 1 individuo.

Orden EDENTATA, Familia DASYPODIDAE, Dasypodidae indet.: 1 individuo. 


\section{Interpretación del material}

La muestra total estudiada consiste en restos óseos de algo más de 100 individuos de distintos taxa, discriminados por localidades en la siguiente forma: Las Cuevas, restos de 37 individuos; Potrero Grande, restos de 25 individuos; Cerro El Dique, restos de 43 individuos.

Si bien el número de individuos (número mínimo) contenido en las muestras parciales no es grande, puede considerárselo como representativo del contexto etnozoológico para cada una de las aldeas, ya que no medió un criterio selectivo apriorístico en su recolección y fueron obtenidas en excavaciones de diferentes unidades de los sitios de asentamiento (habitaciones, basurales, patios centrales, etc.).

Desde el punto de vista zoogeográfico, todos los taxa reconocidos se hallan dentro de su área de distribución actual. Sería sumamente aventurado intentar algún tipo de especulación ambiental en base al material examinado, pues él mismo representa una muestra de elementos faunísticos en alguna medida ya seleccionados -de acuerdo con necesidades variables- por los primitivos habitantes de estas aldeas prehispánicas. De cualquier manera en las muestras no han quedado evidenciadas, si las hubo, situaciones ambientales distintas de las del presente para la misma zona.

Tomadas las tres aldeas en conjunto, es claro el predominio de los camélidos del género Lama sobre el resto de los elementos faunísticos (Figura 1), ya que su frecuencia oscila entre $62.5 \%$ (Cerro El Dique) hasta $81 \%$ (Las Cuevas). Excepto dos casos, Chinchilla sp. y V. vicugna en Cerro El Dique y Las Cuevas, respectivamente, cada uno de los restantes taxa reconocidos representa poco más de $5 \%$ del total, por lo que su frecuencia no es significativa.

Para una de las aldeas -Cerro El Dique- los chinchíllidos del género Chinchilla constituyen por su frecuencia (20\%) el único otro elemento significativo dentro del contexto faunístico. En Las Cuevas, aparte de Lama sp., es otro camélido el que alcanza valores relativamente significativos: $V$. vicugna, con casi 11\%; los otros taxa -al igual que en Potrero Grande, con la excepción ya señalada de Lama sp.no superan en promedio una frecuencia de $5 \%$. De ahí que se prestará especial atención a los distintos aspectos vinculados a los camélidos de América del Sur que parecen haber tenido gran importancia en la vida cotidiana de los antiguos pueblos del Noroeste Argentino.

\section{Los camélidos}

Los camélidos sudamericanos, familia Camelidae, incluyen actualmente dos géneros: Lama y Vicugna. Alguna especie del primero está representada ya en sedimentos asignables al Pleistoceno Temprano de Argentina. La única especie viviente de Vicugna, $V$. vicugna, estaría ya presente en el Pleistoceno Tardío de la provincia de Buenos Aires y Tarija, Bolivia (López Aranguren 1930; Cabrera 1931); de ser ello correcto, la especie que vivió en la llanura pampeana debió ser al menos una subespecie distinta de la actual considerando los especiales requerimientos ecológicos de ésta. Resulta más lógico pensar que la forma del Pleistoceno Tardío de la llanura pampeana y la actual sean en realidad especies gemelas, con idéntica morfología esqueletaria pero biológicamente distintas.

Vicugna vicugna, de hábitos eminentemente orófilos, habita desde el sur del altiplano de Perú, el oeste de Bolivia hasta el noroeste de Argentina y la parte contigua de Chile (Cabrera 1960).

Lama incluye tres especies vivientes: L. guanicoe, L. glama y L. pacos. La primera, el guanaco, es la más plástica en cuanto a sus requerimientos ambientales, pues habita desde el sur de Perú, a más de 5000 m.snm, por el oeste hasta el sur de Patagonia y la costa pacífica entre Atacama y la provincia de Colchagua (Chile), y por el este hasta la costa atlántica en Patagonia y sur de la provincia de Buenos Aires.

Lama glama y L. pacos habitan, únicamente al estado doméstico, en el sur de Perú, oeste de Bolivia y noroeste de Argentina, y sur de Perú y oeste de Bolivia, respectivamente.

De lo expuesto se desprende que de las supuestas cuatro especies vivientes de camélidos sudamericanos, sólo dos se encuentran en estado silvestre: la vicuña y el guanaco. Al respecto, Cabrera y Yepes (1960: 77) sostienen que si bien los conquistadores conocieron a la llama sólo en domesticidad, "en tiempos remotos hubo un animal idéntico en estado salvaje, perfectamente distinto del huanaco" basándose en el hallazgo de restos fósiles del Pleistoceno de Argentina y Bolivia (Boule 1920; López Aranguren 1930; Cabrera 1931). Cabrera y Yepes sostienen 


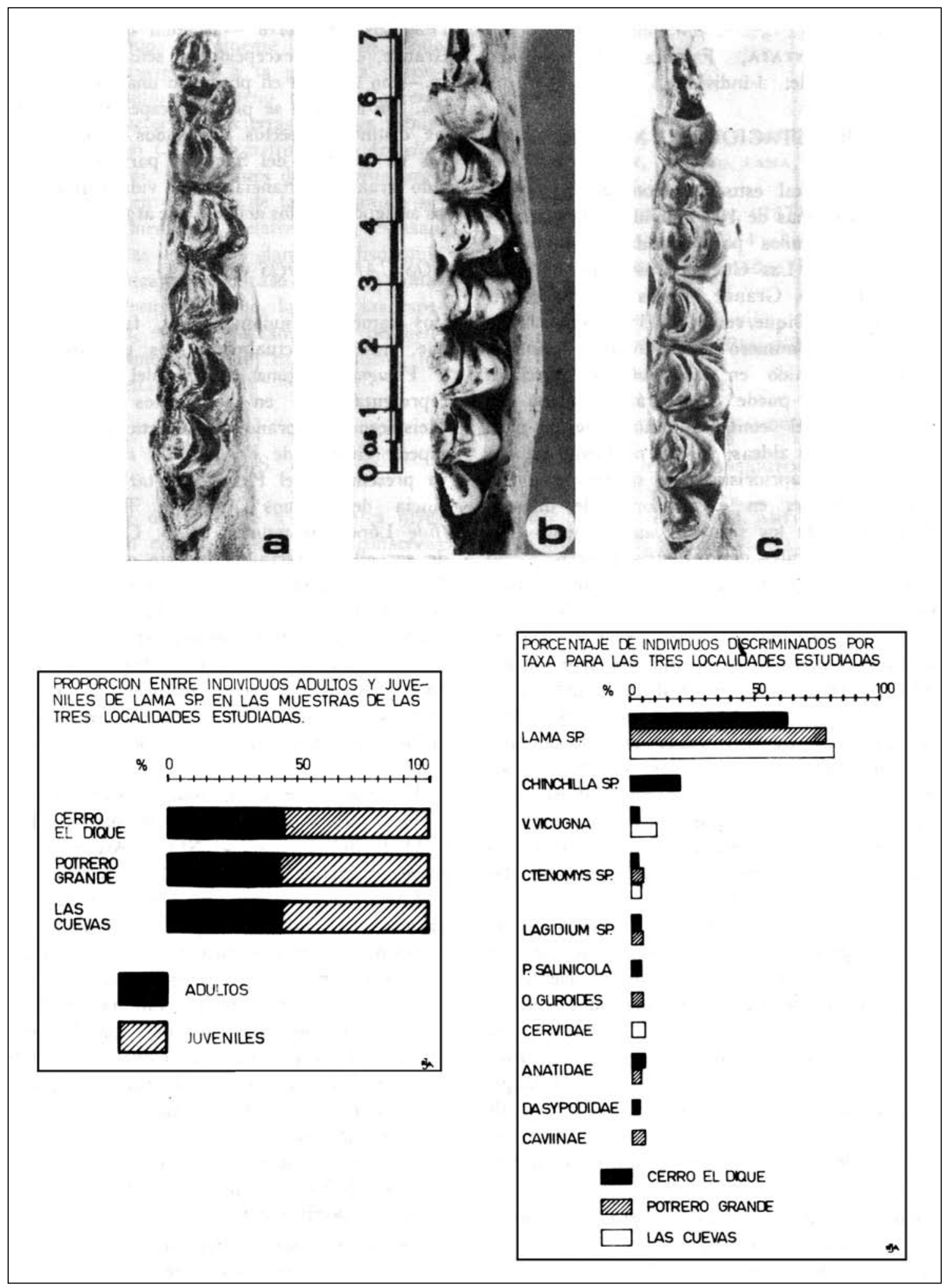

Figura 1. Series molariformes inferiores derechas, en vista oclusal, de camélidos fósiles comparados con Lama guanicoe: a) Auchenia castelnaudi (Gervais 1855), Pleistoceno Tardío de Tarija, Bolivia: plastotipo $\mathrm{n}^{\circ}$ M. 256; b) Lama guanicoe, Chubut, Argentina; c) Auschenia ensenadensis (Ameghino 1899), Pleistoceno Medio, Buenos Aires, Argentina; tipo ${ }^{\circ}$ 9-72. 
también que la alpaca existió en estado silvestre "habiéndose hallado restos subfósiles" (1960: 81), sin hacer mención en este caso a Auchenia lujanensis (Ameghino 1889), del Pleistoceno Tardío de la provincia de Buenos Aires, que López Aranguren (1930) y Cabrera (1931) sinonimizaron con L. pacos.

Esta supuesta clara distinción en tres especies de Lama dista mucho de ser tal desde un punto de vista osteológico, tal como lo expresaran -al menos generalizadamente- algunos autores que se ocuparon del reconocimiento de restos extraídos de yacimientos arqueológicos (Pascual y Odreman 1973; Zetti 1973). Tal distinción adoptada acríticamente por muchos autores se basa, como ya se expresó, fundamentalmente en las publicaciones de Boule (1920), López Aranguren (1930) y Cabrera (1931), de las que estas dos últimas son las monografías más completas sobre camélidos sudamericanos fósiles y actuales, y por ello serán aquí brevemente discutidas.

López Aranguren (1930) sostiene que hay diferencias en la morfología dentaria y craneana que permiten una clara separación entre L. guanicoe, L. glama y L. pacos. Así, indica que L. glama se diferencia de L. guanicoe por el $\mathrm{M}^{1}$ más largo que ancho; por el segundo lóbulo del $\mathrm{M}^{3}$ más ancho y fuerte, y por el petroso que no desciende tan por debajo del borde alveolar, apoyado el cráneo sobre la superficie masticatoria de los molariformes. Las dos primeras "diferencias" son simplemente variaciones debidas al estado de desgaste de los molariformes y probablemente intraespecíficas; la tercera es una variación debida a la edad del ejemplar-consecuencia del desgaste del plano masticatorio- y sexual y/o intraespecífica.

Por su parte, Cabrera (1931) diferencia a L. glama de L. guanicoe por la rama ascendente de la mandíbula más ancha y el entostílido del $\mathrm{M}^{3}$ menos indicado en la primera; ambas son "diferencias" que manifiestan alta variación individual.

En resumen, los supuestos caracteres distintivos establecidos por los autores citados -en especial aquellos referidos a la morfología dentaria- son tan variables que todos ellos pueden hallarse en una pequeña muestra de material osteológico de L. guanicoe, por lo cual se concluye que al menos con elementos óseos aislados y fragmentarios no es posible distinguir L. glama de L. guanicoe.
Respecto a $L$. pacos, puede distinguirse de la llama o guanaco por el carácter señalado por López Aranguren y Cabrera, esto es, el rostro comparativamente más corto que en las otras dos formas. La morfología dentaria y otras partes esqueletarias no ofrecen diferencias constantes utilizables como diagnósticas, y el carácter señalado sólo podrá utilizarse como distintivo si se cuenta con calificado material a determinar y con una buena serie de material para comparación.

Vicugna vicugna parece ser una buena especie, a juzgar por algunas diferencias osteológicas bastante significativas (incisivos inferiores espatulados, con la raíz abierta y lateralmente comprimida; proporciones relativas de los elementos del esqueleto apendicular), pero tales diferencias no justificarían por sí solas su separación en un género distinto de Lama.

Volviendo a la posible existencia de L. glama en el Pleistoceno Tardío de Bolivia y Argentina ya se expresó que, a criterio de los autores, no puede diferenciarse el material óseo, la más de las veces fragmentario, de aquel de L. guanicoe. Una rápida revisión del plastotipo de Auchenia castelnaudi (Gervais 1855), del Pleistoceno Tardío de Tarija, Bolivia, asignada a L. glama por López Aranguren y Cabrera, y del tipo de Auchenia ensenadensis" (Ameghino 1899) -también atribuida a esa especieavalan lo expresado (Figura 1). ${ }^{2}$

La revisión del material tipo de Auchenia lujanensis (Ameghino 1899), permitió comprobar que ésta es diferenciable de L. glama y L. guanicoe por el rostro comparativamente más corto, por lo cual podría asignarse a L. pacos como lo sostienen López Aranguren y Cabrera. Pero Auchenia lujanensis tiene el rostro más corto que los ejemplares de L. pacos con que se la comparó; la serie molariforme es también más corta, comparable a aquella de V. vicugna. Por tanto, es probable que se trate de una especie extinguida de camélido, tal como lo señalara Ameghino, con características morfológicas bastante similares a las de L. pacos.

Ambas piezas, pertenecientes a la colección paleontológica del Museo de La Plata, llevan los números M. 256 y 9-72, respectivamente. 
También es conveniente señalar aquí que las cuatro especies vivientes de camélidos sudamericanos son interfecundas, produciendo híbridos indefinidamente fértiles, lo que per se no hablaría en favor de una escisión específica de la llama y el guanaco -y tal vez de la alpaca- ya que no hay otras diferencias que avalen tal proceder, al menos desde un punto de vista osteológico.

Si se considera -como ya se expresara- que la llama y la alpaca se conocen únicamente como formas domésticas y que no hay evidencia indudable de su anterior existencia al estado silvestre, es válido suponer que ambas son el resultado de selección zootécnica a partir de un agriotipo único, o selección a partir de híbridos entre especies silvestres (guanaco y vicuña). Más aún, las diferencias morfológicas externas de L. glama y L. pacos entre sí y con respecto a las especies silvestres, e incluso las que pudieren reflejarse en el esqueleto -en el caso de $L$. pacos-, no son mayores que las que se observan entre diferentes razas de mamíferos que han pasado por un largo proceso de domesticación (Canis familiaris, Equus caballus).

\section{Discusión}

De lo hasta aquí expuesto se desprende que los restos atribuibles a Lama sp. son los más abundantes en las muestras de material óseo examinadas.

Esta situación se repite en distintos sitios arqueológicos del Noroeste Argentino estudiados por otros investigadores, quienes además hicieron referencia al hecho de que casi con exclusividad en los camélidos de este género se observa la existencia de restos de ejemplares juveniles y adultos en proporciones variables (Núñez Regueiro 1974; Tarragó 1974).

Esta discriminación en individuos jóvenes y adultos fue interpretada por los dos autores citados como el resultado de una caza selectiva, interpretación que no parece ajustarse al análisis conjunto del elemento táctico, o al menos no es la más probable. ${ }^{3}$

3 Núñez Regueiro (1974: 178) sostiene que los restos de camélidos exhumados de basureros de Campo Colorado, Salta, pertenecen a guanacos. De acuerdo con lo expresado al tratar los aspectos vinculados a los camélidos de América del Sur, tal asignación a una especie en particular carece de fundamento real.
En efecto, si se consideran las prácticas ganaderas actuales y más aún las vinculadas a la ganadería de llamas en Perú, donde más intensamente se la practica, se verá que esa "selectividad" responde más claramente a un manejo ganadero que a la caza.

Todo manejo ganadero implica una separación por clases, en edades y sexos, y el momento de la incorporación al consumo del ganado depende de su destino productivo final (carne, piel, carga, etc., o todas ellas en conjunto). En la ganadería de llamas practicada en Perú la hacienda se distribuye por "puntas", es decir, un conjunto de animales con iguales características: anachos o machos reproductores, machos para carga, hembras con cría, machos y hembras con menos de tres años (ancutas), etc. En estos camélidos hay una utilización múltiple. Así los ejemplares de ambos sexos que aún no llegaron a la edad reproductiva se los usa para carne, los machos que no se usan para la reproducción se los castra y destina para carga; para el caso de la alpaca ambos sexos se utilizan como reproductores hasta los siete años, edad en que se destinan únicamente a la extracción de lana o para carne (Cabrera y Yepes 1960).

Debe tenerse en cuenta que el material aquí estudiado proviene no sólo de basureros, sino también de distintas unidades de las tres aldeas y fue analizado en conjunto - a posteriori de su estudio por unidades-a los fines de aprehender una visión totalizadora del contexto faunístico para cada una de las aldeas en cuestión. Así, en las tres localidades se observa un leve predominio del porcentaje de individuos jóvenes sobre los adultos sólo en el caso de Lama sp. De haberse desarrollado una caza selectiva, no se explica por qué ella no se efectuó al menos sobre otro camélido, V. vicugna, cuya frecuencia es significativa en Las Cuevas, el más antiguo de los sitios de asentamiento y donde todos los restos de esa especie corresponden a individuos adultos.

En conclusión, la evidencia disponible de las tres aldeas prehispánicas estudiadas, en base a un método deductivo actualista, parece responder a la hipótesis planteada de que hubo un manejo ganadero de alguna forma de camélido del género Lama por parte de sus pobladores.

Respecto a los demás taxa reconocidos, ya se expresó que junto con Lama sp. y V. vicugna es Chinchilla sp. el otro elemento significativo. Su frecuencia es del $20 \%$ en las muestras de Cerro El Dique, localidad en 
que se observa el menor porcentaje de individuos de Lama sp. (62.5\%) para los tres sitios estudiados.

La frecuencia significativa de Chinchilla sp. para esta localidad puede interpretarse como el resultado de la existencia de poblaciones silvestres más numerosas de este roedor en la región, ya que actualmente están en franco proceso de retracción. Es posible que se haya intentado un proceso de domesticación o por lo menos de mantenimiento en semicautividad de la chinchilla, intento que no habría prosperado dado sus especiales requerimientos (el primer criadero en Argentina data de 1923). Al respecto cabe señalar que a lo largo del tiempo los distintos representantes de la fauna silvestre incorporados al régimen de productividad han llegado como tales hasta el momento actual.

En la retracción de este roedor ha tenido gran influencia la acción del hombre, cuando menos en épocas recientes. La frecuencia significativa de sus restos en sitios arqueológicos podría indicar ya una manifiesta presión de caza, dada la relativa facilidad de captura respecto a otro chinchíllido similar que habita en las mismas zonas, Lagidium, cuyas poblaciones son aún importantes.

Hasta aquí han sido sumariamente expuestas las interpretaciones que pueden darse al material óseo de vertebrados extraído de estos yacimientos arqueológicos. No se pretende concluir que sean las únicas posibles. Simplemente se ha utilizado en este análisis el punto de vista de otra disciplina -la zoológica- que no está ni debe estar alejado del de la antropología, pues sólo el trabajo conjunto de todos aquellos estudiosos realmente interesados en el devenir cultural de los pueblos, pasados y presentes, conducirá a resultados positivos.

Agradecimientos Distintos aspectos del tema desarrollado en esta nota fueron ampliamente discutidos con los Dres. Eduardo Cigliano, Rosendo Pascual y Rodolfo Ruffino y el Lic. Horacio Calandra, quienes aportaron valiosas observaciones y sugerencias desde el punto de vista de las disciplinas de su especialidad. A todos ellos, el agradecimiento de los autores.

\section{REFERENCIAS CITADAS}

BOULE, M., 1920. Mission scientifique G. de Créqui-Monfort et E. Sénéchal de la Grange, Mamm. fossiles de Tarija, París.

CABRERA, A., 1931. Sobre camélidos fósiles y actuales de la América Austral. Revista del Museo de La Plata 33: 89-117.

1960. Catálogo de los mamíferos de América del Sur. Revista del Museo Argentino de Ciencias Naturales " $B$. Rivadavia”, Zool, 4 (2): 309-732.

1971. Fitogeografia de la República Argentina. Boletín de la Sociedad Argentina Botánica 14 (1-2): 1-42.

CABRERA, A. y J. YEPES, 1960. Mamíferos de Sudamérica ( ${ }^{\mathrm{a}}$ ed.), vol. 2, Editorial Ediar.

CIGLIANO, E., 1970. Problemas referentes al sitio arqueológico de Las Cuevas, depto. Rosario de Lerma, Salta. Relaciones de la Sociedad Argentina de Antropología N.S. 5 (1): 99-104.

CIGLIANO, E., R. RAFFINO y H. CALANDRA, 1972. Nuevos aportes para el conocimiento de las entidades alfareras más tempranas del Noroeste Argentino. Relaciones de la Sociedad Argentina de Antropología N.S. 6: 225-236.

KNOCHE, W. y V. BORZACOV, 1947. Clima regional. En Geografía de la República Argentina, vol. VII. Sociedad Argentina de Estudios Geográficos, GAEA.

LOPEZ ARANGUREN, D., 1930. Camélidos fósiles argentinos. Anales de la Sociedad Científica Argentina 59: 15-56.
NUÑEZ REGUEIRO, V., 1974. Conceptos instrumentales y marco teórico en relación al análisis del desarrollo cultural del Noroeste Argentino. Revista del Instituto de Antropología de la Universidad de Córdoba 5: 169-190.

PASCUAL, R. y O. ODREMAN, 1973. Estudio del material osteológico extraído de la caverna de Huargo, departamento de Huanuco, Perú. Revista del Museo Nacional del Perú 39: 31-39.

RAFFINO, R. A., 1972. Ms. El período Formativo de la quebrada del Toro. Informe al CONICET.

RAFFINO, R. y J. TOGO, 1970. El yacimiento arqueológico de Cerro El Dique (nota preliminar), depto. Rosario de Lerma, Salta. Revista Itá Aripí, Depto. de Antropología y Folklore Concordia 1.

RINGUELET, R., 1961. Rasgos fundamentales de la zoogeografía de la Argentina. Physis 22 (63): 151-170.

TARRAGO, M., 1974. Aspectos ecológicos y poblamiento prehispánico en el valle Calchaquí, provincia de Salta, Argentina. Revista del Instituto de Antropología de la Universidad de Córdoba 5: 195-225.

ZETTI, J., 1973. Paleoetnozoología de Tastil. En Tastil, una ciudad preincaica argentina. Ediciones Cabargón, Buenos Aires. 